\title{
Achieving Success under Pressure in the Conservation of Intensely Used Coastal Areas
}

\author{
Fiorenza Micheli ${ }^{1}$ and Federico Niccolini ${ }^{2}$
}

\begin{abstract}
Understanding how biological conservation and socioeconomic development can be harmonized in socialecological systems is at the core of sustainability science. We present the case of a Mediterranean marine protected area (MPA), the Tavolara-Punta Coda Cavallo MPA, that exhibits high ecological performance under intense pressure from fishing, tourism, and coastal development. This case study illustrates how socioeconomic development and significant conservation benefits can coexist, even in a challenging context. Based on this case study, we present a framework for what elements and interactions have determined the high ecological performance of this MPA, and highlight the key leverages that have enabled ecosystem recovery. In particular, the most critical elements underlying high performance were sufficient leadership and knowledge to identify a conservation vision and to catalyze some key actors in the implementation of this vision. Thus, success was ultimately determined by the ability of the leadership of the MPA to devise and implement an effective strategy, with the support and participation of key actors that were external to the MPA organization. The insights from this case study may be applicable to improving MPA management in other systems with similar characteristics, including high human pressures and the presence of an MPA authority.
\end{abstract}

Key Words: conservation performance; marine protected areas; Mediterranean; social-ecological systems; Tavolara-Punta Coda Cavallo MPA; Visionary Organization

\section{INTRODUCTION}

Ecosystems worldwide are in decline, with consequent economic and social losses for local and global human communities (Millennium Ecosystem Assessment 2005). In recent years, there has been increasing awareness and appreciation that the persistence of ecosystems and human well-being can be achieved only by maintaining critical links between the ecological and human components of coupled social-ecological systems (SESs) (Berkes and Folke 1998). Focusing on whole SESs is crucial for understanding change, e.g., biodiversity loss and decreasing food security, and for guiding policy and governance transformations for reversing these changes and increasing the resilience of SESs to current and future pressures (e.g., Gordon and Enfors 2008, Carpenter et al. 2009).

Protected areas constitute an important approach to promoting healthier ecosystems and more responsible socioeconomic development within SESs. In the marine environment, 5880 marine protected areas (MPAs) had been established globally by 2010 , which covered $1.17 \%$ of the world's oceans (Fox et al. 2012). Nations worldwide are striving to expand protection towards the target set by the Convention on Biological Diversity of protecting at least $10 \%$ of each ecoregion by 2020 (Fox et al. 2012).

Despite a large body of evidence that MPAs can provide significant benefits (Gell and Roberts 2003, Micheli et al. 2004, 2012, Worm et al. 2006, Mascia et al. 2010, McCook et al. 2010), studies have also highlighted continued diversity loss (Jones et al. 2004, Graham et al. 2008, Mora and Sale
2011) and negative impacts on local marine users (Christie et al. 2003, Hilborn et al. 2004, Mascia et al. 2010). Thus, even though examples of success in achieving conservation and socioeconomic targets exist (Alcala and Russ 2006, McCook et al. 2010), there are many failures. MPA performance needs to be improved in order to halt environmental and socioeconomic decline (Mora and Sale 2011).

The marine governance and management transformations needed to reverse such decline have proven to be extremely difficult to achieve (Lambin 2005, Gelcich et al. 2010). This is due to many reasons, including the complexity and nonlinearity of feedbacks within SESs; a lack of political will, financial and human resources, and legal authority to support transformation; weak or missing institutions; and poor public support (Crowder et al. 2006, Gelcich et al. 2010). Meeting these challenges requires analyses of the key elements that underlie positive transformations in the cases where these have occurred. Unfortunately, in contrast to the frequent documentation of failure, analyses of successful case studies are not common in the literature (but see Alcala and Russ 2006, Olsson et al. 2008, Gelcich et al. 2010, Micheli et al. 2012). This limits our ability to learn about good practice examples that may be applicable to improving marine governance and management.

We analyze the case of a superperformer (Guerra 2005), a Mediterranean MPA that has achieved a high ecological performance despite major human pressures within the region. This case study demonstrates that success can be achieved, even under intense pressure, if key leverages are in place. 
These include the processes, actors, and organizational elements that enable shifts away from ecological and social decline, and towards ecosystem recovery and responsible socioeconomic development. Thus, key leverages can set SESs on a path towards a high ecological, social, and economic performance. Based on our analysis of this case study, we identify key leverages that have supported high ecological performance, and propose a conceptual framework for MPA management in intensely used areas. Applying this framework may guide improvements in other systems with similar characteristics.

\section{Marine protected areas as complex social-ecological systems}

MPAs worldwide can conceptually follow three fundamentally different models (Fig. 1), though these models represent extremes along a gradient of possible outcomes. Some MPAs minimize direct human influences on ecosystems by protecting remote areas or by strictly enforcing no-take/noaccess regulations (Fig. 1a). For example, Palmyra atoll, in the central Pacific Ocean, is a highly effective MPA that is removed from direct human influences and uses because of its remote location and historical lack of human settlements (Stevenson et al. 2007). In the establishment of these MPAs, social and natural systems were viewed as separate, and in fact the goal was to maintain the natural system removed and insulated from human influences. These MPAs play an important conservation role but are generally impossible to establish in intensely used seascapes, or they require major investments in enforcement (Fraschetti et al. 2009).

Fig. 1. Marine protected area (MPA) types: (a) some MPAs effectively remove or minimize direct human influences on natural ecosystems by protecting remote areas or by strictly enforcing no-take/no-access regulations; (b) other MPAs are paper parks, where the human-natural interaction is not mediated by effective institutions; and (c) MPA Authorities or other institutions can act as effective mediators of the interaction between the social (SS) and the ecological systems (ES).
A.

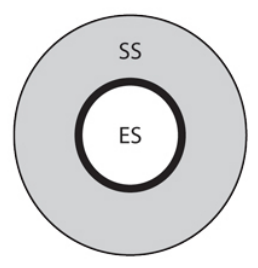

B.

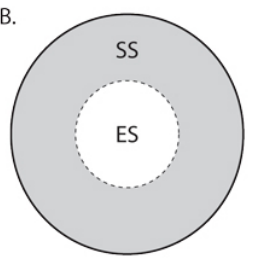

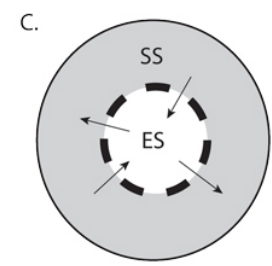

In most cases, natural and human systems are not separated or separable, but these settings can differ in how the humannatural interactions are managed. Many MPAs (Fig. 1b) are effectively paper parks, where the human-natural interaction is not mediated by effective institutions and results in resource overexploitation and user conflict. In fact, many MPAs do not provide measurable ecological or socioeconomic benefits (for example, Abdulla et al. 2008, Mora and Sale 2011). Following Ostrom (2005), by institution we refer to the rules, norms, values, and strategies that people use to organize their interactions. In a third scenario (Fig. 1c), an MPA Authority (MPAA) or other local informal and formal institutions (McCay and Jones 2011) act as the mediator of the complex and dynamic interactions between the natural and the social system. Australia's Great Barrier Reef Marine Park has been highlighted as highly effective in mediating natural-human interactions (Olsson et al. 2008, McCook et al. 2010).

In all three models, as well as intermediate types, the MPAA or other institutions may act as an organizational mediator between the socioeconomic actors and the natural environment. However, such mediation is most effective in the last model (Fig. 1c), which creates the conditions to achieve success under pressure. External drivers that are beyond the MPAA management authority and capacity, such as landbased and climatic drivers, may negatively impact all MPA models. However, effective management of the interactions between the social and ecological components of these systems may be able to partly address these external drivers through mitigation and adaptation. We examine the elements and feedbacks that may underlie success by using a Mediterranean case study. Success can be defined and assessed according to multiple objectives: biological, economic, social, and political, which are sometimes compatible, sometimes in conflict (e.g., Hilborn 2007). We selected our case study based on evidence of biological success and examined the circumstances that may underlie the achievement of biological conservation objectives (e.g., Hilborn et al. 2005). Specifically, we investigate the human context of this biological success, and the mechanisms through which behaviors were modified to enable this conservation achievement.

\section{Success under pressure in practice: analysis of a superperformer}

Densely populated or intensely used coastal systems present tremendous challenges for reconciling biological conservation with social and economic development. Even when organizations with a conservation mission (e.g., MPAAs) are in place, they often fail to achieve their goals because of intense and escalating pressures from multiple users and sectors (Hilborn et al. 2004, Mora and Sale 2011). The ultimate test of whether positive conservation outcomes can be achieved under pressure can come only from intensely used coastal areas. Thus, it is especially important to identify examples of success under these challenging settings. Such case studies provide unique opportunities to examine what critical elements explain success, and to apply these insights to promote marine management transformation more broadly. 
Fig. 2. Location and size of Mediterranean marine protected areas (from Abdulla et al. 2008 , reproduced with permission by the authors). The black arrow marks the location of the Tavolara-Punta Coda Cavallo.

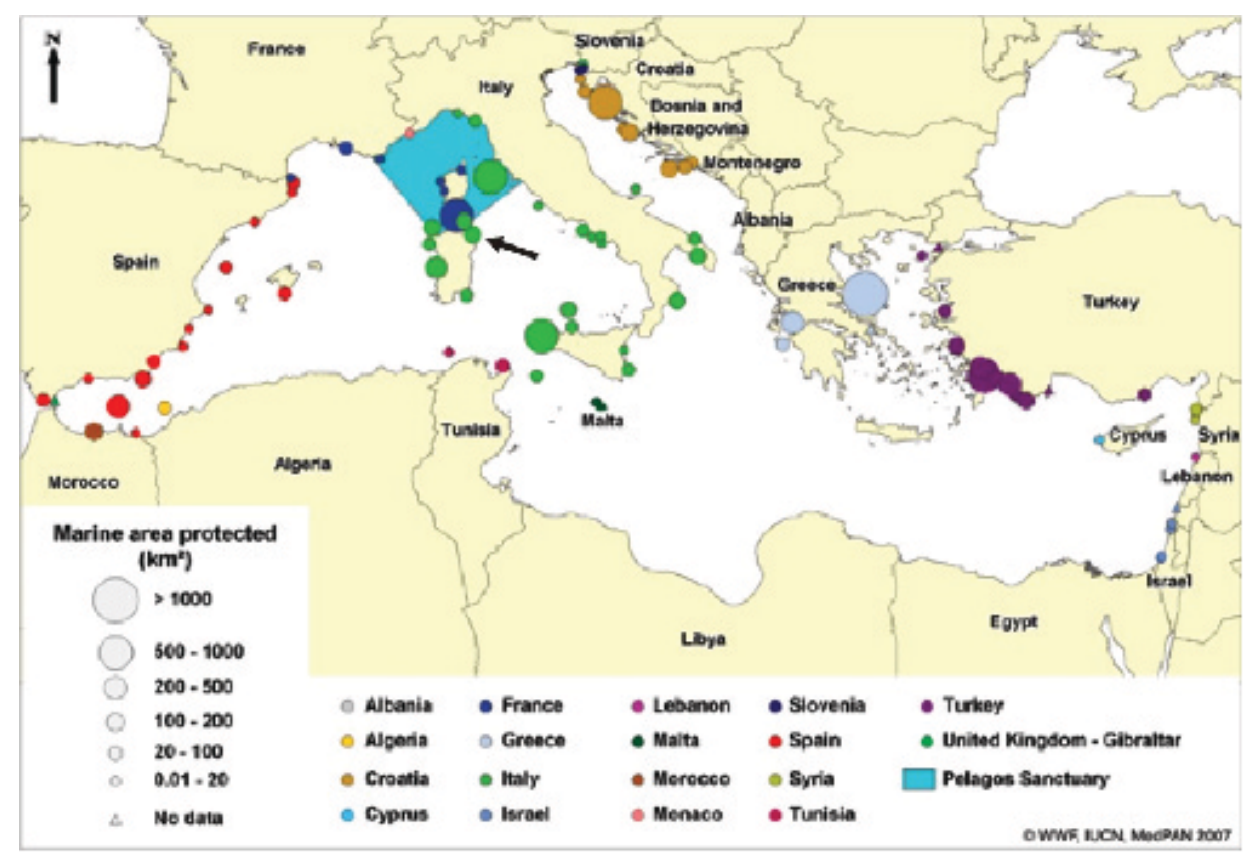

Mediterranean coastal areas are representative of the conflicts and pressures that influence the performance of coastal SESs in many densely populated regions of the world. Human pressure on Mediterranean marine and coastal ecosystems is tremendously high due to the presence of densely populated coastlines, particularly in the summer months (450 million people in the Mediterranean countries, supplemented by an additional 220 million tourists [UNEP 2005]), intense fishing pressure (Coll et al. 2011), extremely high numbers of invasive species (Molnar et al. 2008), and impacts from climate change (Lejeusne et al. 2010). Recent analyses of the cumulative impacts of human activities in the Mediterranean have ranked its ecoregions among the most heavily impacted worldwide (Halpern et al. 2008) and have characterized this marine region as "under siege" (Coll et al. 2011). Such intense pressure has resulted in major alterations of Mediterranean ecosystems and widespread conflict among marine users (Lotze et al. 2006, Airoldi and Beck 2007, Abdulla et al. 2008, Ferretti et al. 2008).

More than 100 MPAs covering $0.4 \%$ of the Mediterranean already exist (Fig. 2) (Abdulla et al. 2008), and more are planned to meet the Convention for Biological Diversity's target of $10 \%$ protected by 2020. However, most Mediterranean MPAs fail to achieve their conservation goals. Decline in key habitats and species is reported for most MPAs (Abdulla et al. 2008). This is explained partly by widespread inadequate capacity: nearly two-thirds of MPAs lack management plans and have insufficient infrastructure and resources (Abdulla et al. 2008).

These Mediterranean-wide trends were supported by a field assessment of the efficacy of Italian MPAs, which documented positive effects on coastal fish assemblages in only four of 15 reserves examined (Guidetti et al. 2008), and thus indicated that most existing MPAs are paper parks (Fig. 1b). Three of the four effective MPAs-Miramare, Torre Guaceto, and Portofino (established in 1986, 1991, and 1998, and measuring 120, 2227, and 346 ha, respectively) have made significant investments in enforcement of no-take regulations (Fig. 1a). Thus, high enforcement levels were proposed as the mechanism for achieving the MPAs' conservation goal of recovering depleted populations (Guidetti et al. 2008). However, the fourth system, the Tavolara-Punta Coda Cavallo (TPCC) MPA (established in 1997, with a total surface area of 15,537 ha), in northeastern Sardinia, Italy (Fig. 2), does not rank high in enforcement level and yet has the highest biological performance relative to nearby reference areas and all other MPAs, both in terms of total fish biomass and abundance and size of top predators (di Franco et al. 2009, Sala et al. 2012).

The TPCC also ranked highest in fish biomass in a comparison of 32 MPAs and unprotected locations throughout the Mediterranean, with total biomass 1.3-31 times greater than 
the other locations examined (Sala et al. 2012). Total fish biomass in the TPCC is three times greater than the average of the 12 other Mediterranean MPAs surveyed, and 6.7 times greater than the average of 19 unprotected sites (Sala et al. 2012). One possible interpretation of this result is that the TPCC is a highly productive area that supports abundant fish populations independently of protection. However, comparisons of fish abundance before and after effective protection began show that the large biomass of fish in the TPCC can be attributed to protection, not to unique environmental conditions at this site. In particular, the densities of dusky grouper (Epinephelus marginatus), a large predatory fish commonly targeted by recreational and commercial fishing, showed an average increase of six to11 times, depending on the habitat type considered, within the no-take zones but not outside (Guidetti et al. 2007). The TPCC also has low abundances of alien species, and relatively healthy benthic communities (Ceccherelli et al. 2006, Sala et al. 2012). Despite high Mediterranean-wide mortality of benthic invertebrates from recent heat waves, reef communities below $25-30 \mathrm{~m}$ depth remain healthy and diverse (Cerrano et al. 2000, Garrabou et al. 2009, Huete-Stauffer et al. 2011). The presence of such high abundance of large fishes and rich benthic communities attracts more than 10,000 recreational divers each year, with an estimated total value of the diving sector of US\$17,988,900 per year (Niccolini and Marzo 2009). Scuba diving activity is common in the other effective MPAs, but the TPCC has the highest number of scuba diving operators.

The socioeconomic context of the TPCC MPA is typical of the Mediterranean basin. Thus, this ecological success has been achieved despite tremendous human pressure, including the proximity to industrial areas and commercial fishing harbors (Olbia and Golfo Aranci), and the presence of intensely developed coastlines (e.g., the heavily developed Emerald Coast to the north of the TPCC MPA, which provides a cultural model of unsustainable high-end lifestyle that local youth are attempting to emulate [Niccolini and Del Principe 2008]).

To elucidate what factors and processes may underlie the high ecological performance of the TPCC MPA, we conducted a detailed analysis of this case study, including interviews with diverse stakeholder groups (Appendices 1-2). Our goal was to use the case of this superperformer to identify key leverages that lead to high MPA performance and which may be acted upon in other systems.

\section{METHODS}

Analysis of the socioeconomic and cultural context of the TPCC MPA was aimed at identifying the main linkages and feedbacks between the social and ecological components of the system. The goal was to identify the social, demographic, economic, and cultural factors that influence the performance of the MPA in terms of its environmental conservation goals. Specifically, our analysis focused on (1) the sectors and stakeholders that may affect the ecological condition of the MPA (e.g., coastal development, fishing), and (2) the perceptions and attitudes of different stakeholder groups with respect to the MPA and its conservation vision. We aimed to identify both the factors that explain the documented biological success of the MPA and the opportunities for additional actions aimed at improving the MPA performance in the future.

A series of indicators was selected to describe and quantify the social, economic, and cultural dimensions of the stakeholders' interaction with the MPA (Table 1). To assess the level of public support of the MPA, we selected indicators that measured the awareness, support, and expectation of the MPA, and the general environmental orientation of different sectors and stakeholder groups. We selected additional indicators to assess the perceived or actual impacts of fishing, coastal development, and tourist visitation (Table 1). Some indicators likely have direct influences on MPA performance (e.g., awareness of the existence and role of the MPA, and general environmental orientation of residents and entrepreneurs). In contrast, other indicators (e.g., general demographic and economic indicators) were considered to have smaller direct influence on the MPA performance but to provide contextual information that was important for interpreting results for the other indicators (Table 1). Values of basic socioeconomic and demographic indicators were obtained from published statistics, while for most indicators, data were collected through interviews (Table 1, Appendices 1-6).

Interviews were conducted first with 13 key informants who were selected based on their deep knowledge of the MPA and local communities (e.g., one of the people who had played a key role in the establishment of the MPA, a local underwater photographer and naturalist, school teachers, a local resident well known for his social commitment and volunteer work). Second, unstructured interviews were conducted with the MPA staff to identify potential strengths and weaknesses of this organization. Third, structured interviews were conducted with a broad suite of stakeholders (Appendix 1). To capture the main social-ecological linkages and feedbacks within this system, stakeholders were divided into three categories according to the level of interaction and mutual influence with the other socioeconomic subsystems, the ecological system, and the MPAA (Fig. 3). "Key stakeholders" were actors with strong influence on and frequent interaction with the human and natural components of the MPA. Among these, we identified (1) key entrepreneurs, subdivided into scuba diving operators, local small-scale fishermen (targeting primarily lobster and multiple finfish species), and boat rental operators; and (2) key tourists, i.e., scuba divers and sailors. "Relevant stakeholders" were actors that had some interaction with and 
Table 1. Main indicators used in the analysis ( $\dagger$ : indicators quantified through interviews).

\begin{tabular}{ll}
\hline \hline Category & Indicators \\
\hline Society & \\
Demographic structure & Resident population \\
& Migratory balance \\
& Population density \\
& Old age rate \\
& Family structure \\
Educational potential & Family stability \\
Occupation & Educational potential \\
& Unemployment rate \\
Drug diffusion & Population dependency ratio \\
Criminality & Drug diffusion \\
& Youth delinquency \\
Environmental orientation & Overall criminality \\
& Waste recycling \\
Economy-general & \\
Income & \\
Economical activities composition & Local net income \\
Entrepreneurship & Added value \\
& Distribution of economic activity \\
& Added value composition \\
& Local entrepreneurship \\
& Real entrepreneurship rate \\
& Entrepreneurial dynamic
\end{tabular}

Economy and related cultural aspects-Perspectives of key and relevant entrepreneurs

Knowledge of the MPA among entrepreneurs

Entrepreneurial education in sustainable development

MPA awareness $(\dagger)$

Conservation and sustainability core values diffusion $(\dagger)$

MPA concept: awareness of overall functions of the MPA $(\dagger)$

Diffusion of environmental certifications $(\dagger)$

Level of perception of the use of environmental certifications $(\dagger)$

Level of awareness of environmental certifications $(\dagger)$

\section{Key and relevant activities}

Tourism

Weight of the sector-real

Weight of the sector-structural

Tourism pressure

Potential of the tourism offer

Diving tourist demand segment (Key stakeholders)

Sand tourism demand segment (Relevant stakeholders)

Sand tourism demand segment (Relevant stakeholders)

Tourist satisfaction $(\dagger)$

Sailor tourism demand segment (Relevant stakeholders)
Tourist loyalty $(\dagger)$

Awareness of the MPA (†)

Tourist eco-motivation $(\dagger)$

Real structural incidence

Structural incidence on the local economy

Settlement pressure

Seasonality of arrival flux

Seasonality perceived by entrepreneurs in sectors $(\dagger)$

Diver satisfaction $(\dagger)$

Diver loyalty $(\dagger$

Awareness of the MPA $(\dagger)$

Diver eco-motivation $(\dagger)$

Sailor tourist satisfaction $(\dagger)$ 


\begin{tabular}{|c|c|}
\hline & $\begin{array}{l}\text { Sailor loyalty }(\dagger) \\
\text { Awareness of the MPA }(\dagger) \\
\text { Sailor eco-motivation }(\dagger)\end{array}$ \\
\hline \multicolumn{2}{|l|}{ Fishing } \\
\hline MPA objective sharing & Understanding the benefits of the MPA $(\dagger)$ \\
\hline Collaborative potential & Collaboration possibilities between the MPA and fishermen $(\dagger)$ \\
\hline \multicolumn{2}{|c|}{ Awareness of the effects of human activities on the ecosystem } \\
\hline & Perception of the sustainability of local resources $(\dagger)$ \\
\hline & Perception of the human impact on marine resources $(\dagger)$ \\
\hline Perception of the socioeconomic value of the MPA & Perception of the effect of the MPA on fish stocks $(\dagger)$ \\
\hline Effects on the local economy & Retention of added value by fishing $(\dagger)$ \\
\hline \multicolumn{2}{|l|}{ Coastal development } \\
\hline \multirow[t]{2}{*}{ Structural influence } & 1) Real influence of the sector \\
\hline & 2) Influence of the sector in the local economy \\
\hline \multirow[t]{2}{*}{ Expansion capacity } & 1) Additional human pressure in the MPA \\
\hline & 2) Additional territorial pressure in the MPA \\
\hline
\end{tabular}

influence on the ecosystems and the MPAA. These comprised (1) relevant entrepreneurs, hotel or restaurant owners, and those working in the service and commerce sectors; and (2) relevant tourists (beach tourists) (Table 1). Other stakeholders may have provided additional useful information but had a low influence on the ecosystem and limited interaction with the MPAA, and therefore were not interviewed.

Fig. 3. Subdivision of the social and ecological systems into key, relevant, and other components. Marine Protected Area Authorities (represented by the dashed line) can act on key social and ecological targets to promote improvement within both systems.

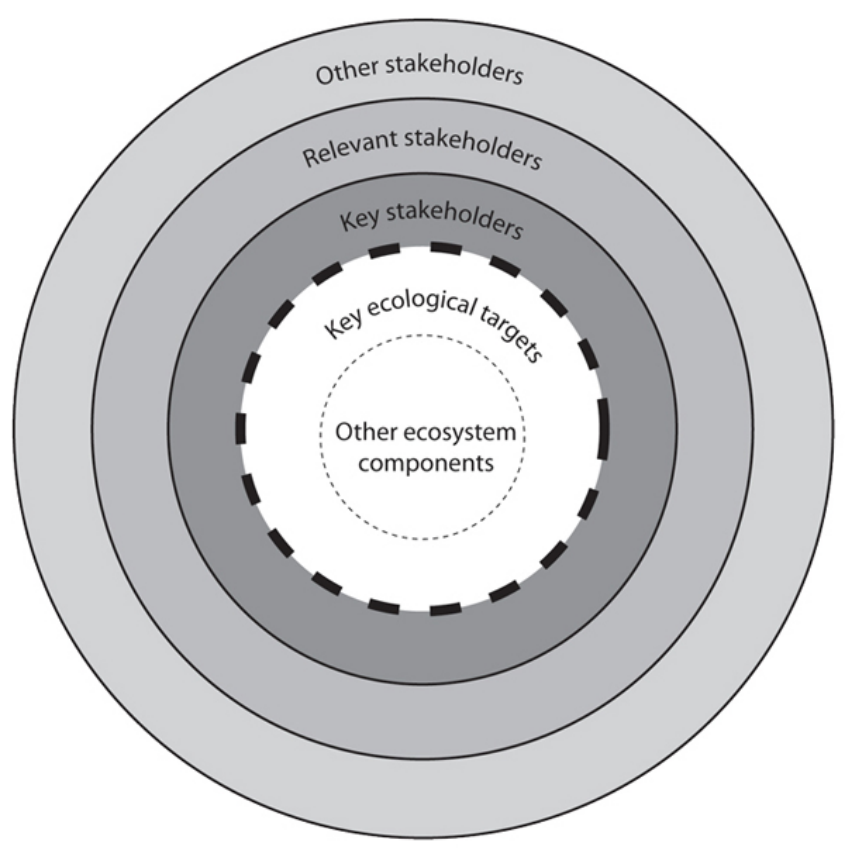

We conducted 375 in-depth interviews and 2834 short interviews which comprised a small subset of the questions asked in the in-depth interviews (Appendices 1-2). Short interviews were used to stratify the sample for subsequent indepth interviews. All interviews were conducted by one of the authors (FN) and a team of 10 graduate students. The number of interviews was designed to include at least $50 \%$ of fishermen and diving centers, $30 \%$ of boat rentals, $10 \%$ of hotel and restaurant owners, and $5 \%$ of service and commerce entrepreneurs in the towns with coastlines within the park (Loiri Porto San Paolo, San Teodoro, and Olbia), based on registers of the Chamber of Commerce.

For each stakeholder group, we determined the frequencies of different answers to each question. Indicator values obtained from published records were compared to regional or national statistics or were evaluated based on their temporal trends (Table 2, Appendices 3-4). Evaluation of key ecological factors was conducted based on published studies. We then conducted an interpretive analysis to identify the most important pressures and leverages, using the qualitative analytical framework of a SWOT analysis, which is a strategic planning method used to evaluate the strengths, weaknesses, opportunities, and threats involved in a project. It entails specifying the objective of the project (i.e., the MPA conservation mission) and identifying the internal strengths and weaknesses (within the MPAA, in this case) and external threats and opportunities (within the broader ecological and social systems) that are favorable or unfavorable to achieving the objective. Each potential threat or opportunity was evaluated through the lens of two factors: its importance (scored as 0: low importance, or 1: high importance), and its magnitude or intensity (on a $0-2$ scale). The overall relevance was calculated as the product of these two scores. Strengths and opportunities with high relevance scores were seen as key leverages that have shifted or are capable of shifting the SES on a trajectory towards the conservation and sustainable development vision. We used this qualitative analytical framework to identify the factors that may have underlain the high biological performance of the MPA, and the opportunities 
Table 2. Values of the social, economic, and cultural indicators. Average values are reported separately for the two core municipalities within the marine protected area (MPA) (Loiri Porto San Paolo and San Teodoro; avg. of core area) and for these and the larger town of Olbia, which lies outside the MPA but has part of its coastlines in the MPA (total avg.). The approach used to interpret indicator values is also reported (evaluation criteria). Values were compared to the national and regional averages to determine if local values were greater or lesser than, or comparable to, those observed at these broader scales (1); when temporal data were available, trends were assessed as increasing, decreasing, or stationary (2); percent of responses from interviews were assessed based on their absolute value (3). The last column reports the assessment of each indicator as a threat (T) or opportunity (O) based on the criteria listed. (TPCC: Tavolara-Punta Coda Cavallo)

\begin{tabular}{|c|c|c|c|c|c|c|}
\hline Category & Indicator & Measures & $\begin{array}{c}\text { Avg. of core } \\
\text { area }\end{array}$ & Total avg. & $\begin{array}{c}\text { Eval. } \\
\text { criteria }\end{array}$ & Assessment \\
\hline & & Society (general) & & & & \\
\hline \multirow[t]{2}{*}{ Demographic structure } & Population dynamics & $\begin{array}{l}\text { Demographic balance (2001- } \\
\text { 2005) }\end{array}$ & $\begin{array}{c}378 \\
3.38 \%\end{array}$ & $\begin{array}{l}3590 \\
1.73 \%\end{array}$ & 1 & $\mathrm{O}$ \\
\hline & & $\begin{array}{l}\text { Average annual rate of } \\
\text { increase (2001-2005) }\end{array}$ & & & & \\
\hline Educational potential & Educational potential & $\begin{array}{l}\% \text { of population between } 2 \\
\text { and } 17 \text { years of age }\end{array}$ & - & $15.8 \%$ & 1 & $\mathrm{O}$ \\
\hline Occupation & $\begin{array}{l}\text { Population } \\
\text { dependency ratio }\end{array}$ & $\begin{array}{l}\text { Not in working-age } \\
\text { population (age between } 0 \\
\text { and } 14 \text { years or over } 65 \\
\text { years)/potentially working } \\
\text { population (age between } 15 \\
\text { and } 64 \text { years) (comparison } \\
2001-2005 \text { ) }\end{array}$ & 0.413 & 0.362 & 1 & $\mathrm{O}$ \\
\hline Drug diffusion & Drug diffusion & $\begin{array}{l}\text { No. of reports for drug } \\
\text { reasons (Avg. 2004-2005) }\end{array}$ & - & 91 & 2 & $\mathrm{~T}$ \\
\hline Criminality & Youth delinquency & $\begin{array}{l}\text { Number of people under } 18 \\
\text { years of age (Avg. 2004- } \\
2005 \text { and Avg. 2002-2003) }\end{array}$ & - & 16 & 2 & $\mathrm{~T}$ \\
\hline \multirow[t]{2}{*}{$\begin{array}{l}\text { Environmental } \\
\text { orientation }\end{array}$} & Waste recycling & $\%$ of recycled waste & - & $2.8 \%$ & 1 & $\mathrm{~T}$ \\
\hline & \multicolumn{5}{|c|}{ Economy and related cultural aspects-Perspectives of key and relevant stakeholders } & \\
\hline $\begin{array}{l}\text { Knowledge of the MPA } \\
\text { among entrepreneurs }\end{array}$ & $\begin{array}{l}\text { Conservation and } \\
\text { sustainability core } \\
\text { values diffusion }\end{array}$ & $\begin{array}{l}\% \text { of operators that believe } \\
\text { the MPA is an asset for } \\
\text { future generations (Values } \\
\text { rooted; Present; Absent; } \\
\text { Aversion; Indifference) }\end{array}$ & - & $\begin{array}{c}22.5 \% ; 18.0 \% ; 11.2 \% \\
5.6 \% ; 42.7 \%\end{array}$ & 3 & $\mathrm{~T}$ \\
\hline \multirow[t]{2}{*}{$\begin{array}{l}\text { Entrepreneurial } \\
\text { education in sustainable } \\
\text { development }\end{array}$} & $\begin{array}{l}\text { Level of awareness } \\
\text { of environmental } \\
\text { certifications }\end{array}$ & $\begin{array}{l}\text { No. of entrepreneurs that } \\
\text { know about environmental } \\
\text { certifications } \times 100 / \text { total } \\
\text { entrepreneurs interviewed }\end{array}$ & $63.0 \%$ & $57.0 \%$ & 3 & $\mathrm{~T}$ \\
\hline & \multicolumn{5}{|c|}{ Key and relevant activities-Tourism } & \\
\hline Tourism pressure & Settlement pressure & $\begin{array}{l}\text { Dwellings not occupied by } \\
\text { residents/dwellings occupied } \\
\text { by residents (2001) }\end{array}$ & $\begin{array}{l}4.41(8088 / \\
1833)\end{array}$ & $1.12(18,379 / 16,407)$ & 1 & $\mathrm{~T}$ \\
\hline \multirow[t]{3}{*}{$\begin{array}{l}\text { Potential of the tourism } \\
\text { offer }\end{array}$} & $\begin{array}{l}\text { Seasonality perceived } \\
\text { by entrepreneurs in } \\
\text { sectors }\end{array}$ & $\begin{array}{l}\text { Clients in the high season } \\
\text { (July-August) } \times 100 / \text { annual } \\
\text { clients }\end{array}$ & $60.0 \%$ & $55.0 \%$ & 1 & $\mathrm{~T}$ \\
\hline & & $\begin{array}{l}\text { Clients in the medium-high } \\
\text { season (from June to } \\
\text { September) } \times 100 / \text { annual } \\
\text { clients }\end{array}$ & $86.0 \%$ & $79.0 \%$ & 1 & $\mathrm{~T}$ \\
\hline & & $\begin{array}{l}\text { Clients from April to } \\
\text { October } \times 100 / \text { annual clients }\end{array}$ & $98.0 \%$ & $92.0 \%$ & 1 & $\mathrm{~T}$ \\
\hline $\begin{array}{l}\text { Diving tourist demand } \\
\text { segment }\end{array}$ & $\begin{array}{l}\text { Diver satisfaction } \\
\text { (scale from } 1 \text { to } 10 \text { ) }\end{array}$ & $\begin{array}{l}\text { Environmental factors } \\
\text { (water, air and seabed } \\
\text { quality, landscape, beach and } \\
\text { coast) }\end{array}$ & - & 8.80 & 3 & $\mathrm{O}$ \\
\hline
\end{tabular}




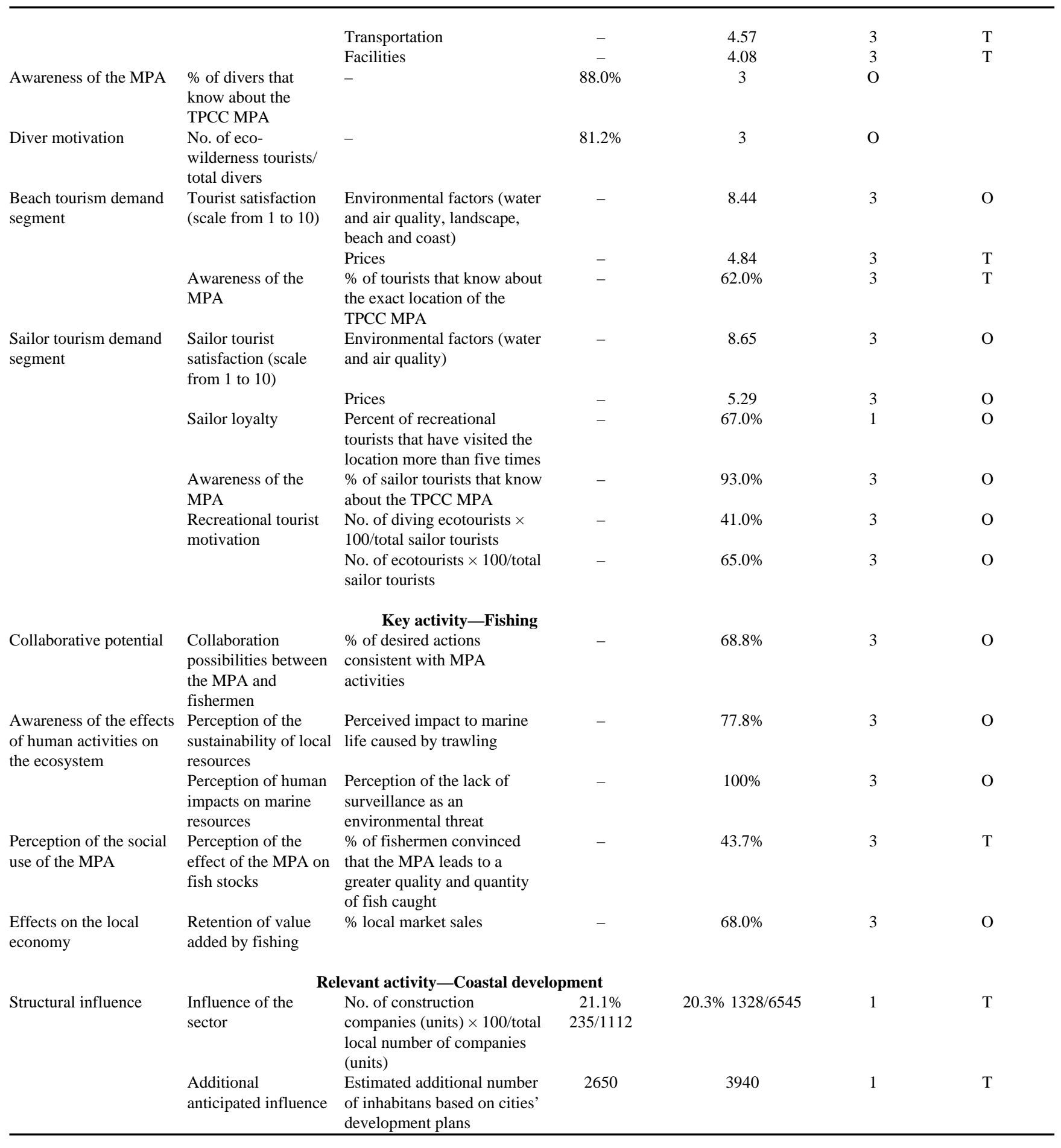

for future actions aimed at further improvement of the MPA performance.

\section{RESULTS}

Interviews with key informants and MPAA staff highlighted that the TPCC was established as the result of the efforts, in the 1980s-early 1990s, of a few individuals. A crucial change occurred in 2004, seven years after the MPA was established, when the MPAA recruited a new director. The new MPA director in turn recruited competent temporary staff, conducted aggressive fund raising, and established a series of collaborations with social and natural scientists within national and international academic institutions and environmental agencies. Other key actions that were 
Table 3. Main weaknesses, threats, strengths, and opportunities of the Tavolara-Punta Coda Cavallo Marine Protected Area (MPA). The importance of each weakness, threat, strength, and opportunity was scored as $0=$ low importance or $1=$ high importance; their intensity (or magnitude) was scored as $0=$ low, $1=$ medium, or $2=$ high intensity.

\begin{tabular}{|c|c|c|c|}
\hline System & & Importance & Intensity \\
\hline & Main weakness & & \\
\hline \multirow[t]{2}{*}{ Organization (MPA Authority): } & Limited and uncertain financial and human resources & 1 & 2 \\
\hline & Main threats & & \\
\hline \multirow[t]{2}{*}{ Social system: } & $\begin{array}{l}\text { Troubled local youth, and limited knowledge and appreciation of natural resources } \\
\text { by local youth and entrepreneurs }\end{array}$ & 1 & 2 \\
\hline & Highly seasonal tourism, and pressure for further coastal development & 1 & 2 \\
\hline \multirow[t]{2}{*}{ Ecological system: } & $\begin{array}{l}\text { Evidence of impacts from poor water quality near coastal settlements (e.g., } \\
\text { mucillagenous algal blooms negatively impacting seagrass beds), and recent heat } \\
\text { waves (gorgonian coral mortality) }\end{array}$ & 1 & 1 \\
\hline & Main strength & & \\
\hline \multirow[t]{2}{*}{ Organization (MPA Authority): } & High level of leadership and competence of permanent staff & 1 & 2 \\
\hline & Main opportunities & & \\
\hline \multirow[t]{3}{*}{ Social system: } & $\begin{array}{l}\text { High educational potential of the local population because of large representation of } \\
\text { school-age children }\end{array}$ & 1 & 2 \\
\hline & $\begin{array}{l}\text { Presence of individuals who are strongly supportive of MPA and of a sustainable } \\
\text { development vision }\end{array}$ & 1 & 1 \\
\hline & $\begin{array}{l}\text { Concordance between tourists' stated aspirations and the environmental, } \\
\text { educational, and recreational services that a successful MPA can provide }\end{array}$ & 1 & 2 \\
\hline \multirow[t]{2}{*}{ Ecological system: } & $\begin{array}{l}\text { High potential for recovery of exploited populations (broad size structure and high } \\
\text { biomass of fish within reserves) }\end{array}$ & 1 & 2 \\
\hline & $\begin{array}{l}\text { Abundant healthy habitat (rocky reefs, seagrass beds), particularly offshore, and } \\
\text { refuges from heat waves at depth }\end{array}$ & 1 & 1 \\
\hline
\end{tabular}

highlighted in interviews included the establishment of collaborations between the MPAA and diving operators and divers (20 operators and thousands of divers), and the setting up of permanent moorings for diving boats within the MPA. The MPAA had also granted the small number of licensed commercial fishermen still operating within this area exclusive access privileges to designated zones within the MPA, and had worked with local schools to establish education programs on environmental sustainability and marine conservation. Based on these interviews, the leadership and competence of MPAA staff, and the scarce resources available to the MPAA were identified as the key strength and weakness, respectively, of the MPAA (Table 3).

Interviews with key and relevant stakeholders identified the presence of stakeholders that are strongly supportive of the MPA and the MPAA mission as important factors underlying the success of the MPA (Tables 2-3, Appendices 3-7). In particular, most recreational scuba divers and recreational sailors, and to a lesser extent, beach tourists, were aware of the existence of the MPA (Table 2, Appendix 4), and they revealed a distinct preference for eco- and wilderness tourism compared to luxury or mass tourism (Table 2, Appendix 3), ranked indicators of high environmental quality of the MPA as the attributes that draw them to this location (Table 2, Appendix 5), and showed a high degree of loyalty (94\% sailors, $74 \%$ divers, and $70 \%$ beach tourists had been in the TPCC MPA at least once before [Appendix 6]). Fishermen were also overall supportive of the MPA. Most interviewees supported the role of the MPA in enforcing environmental protection and addressing human impacts on the local ecosystems, and saw the MPAA as an ally in protecting their resources and activity (Table 2 ).

A review of socioeconomic indicators revealed worrisome trends of high diffusion of drugs and high youth delinquency (Tables 2-3) as a major social issue and threat to the SES. Interviews with key and relevant stakeholders also identified the limited knowledge and appreciation of natural resources and of the MPA, particularly among the younger generation, and a lack of environmental awareness and knowledge of the MPA among relevant entrepreneurs as key threats (Tables $2-$ 3). Multiple key informants also stated that addressing such a lack of appreciation for the natural environment among the younger generations is critical. A key opportunity, in this regard, is the high educational potential of the local population, characterized by an age structure that is shifted towards young cohorts (15.8\% of individuals between 2 and 17 years of age, a proportion that is significantly greater than the regional and national average) (Tables 2-3).

A key threat to the SES is also the highly seasonal tourism influx during the summer months, and consequent 
concentration of income during a small fraction of the year, overcrowding, and pressure to develop the coastline to accommodate tourism demand (Tables 2-3). In particular, San Teodoro has one of the highest ratios of nonresidential/ residential homes in Italy, which is indicative of the importance of the tourism sector, and local plans anticipate rapid additional development within the MPA over the next years (Tables 2-3, Appendix 4). These results confirm our expectation of a system under intense pressure from human use and coastal development.

Previous ecological studies had identified the impacts of fishing on fish and benthic communities, the impacts of coastal development on water quality and benthic habitat, and the high mortality of gorgonian corals from recent heat waves as major threats to key ecosystem components (Table 3 ). These studies also highlighted some opportunities to conserve benthic species in spatial refuges, particularly, generally high water quality away from coastal developments, and refuges from the impacts of heat waves at depth (Micheli, unpublished data, Cerrano et al. 2000, Garrabou et al. 2009) (Table 3). These factors, in addition to the documented recovery of target fish species and current high biomass levels, are key contributors to the high ecological performance of the MPA.

\section{DISCUSSION AND CONCLUSIONS}

Good leadership and involvement of key partners have been the crucial mechanisms for the positive outcomes in the TPCC MPA. We propose that, for MPAs that have similar characteristics to our case study (e.g., intense human use of the coastal environment and the presence of a formal MPAA that is responsible for the management of the MPA), success may be determined by the ability of the leadership of an MPAA to devise and implement an effective strategy with the support and participation of stakeholders that are external to the MPAA. Effective evaluation of the SES that informs such actions requires partnerships and collaborations between the MPAA, scientists, and stakeholders (e.g., Castilla 1999, Alcala and Russ 2006). Thus, we propose that a multi-actor governance framework may be a key element of MPA effectiveness more generally. In this case study, it was the MPAA leadership that catalyzed participation and enabled the development of a multi-actor governance framework (e.g., Osborne and Gaebler 1992, Milne et al. 1996, Gerencser et al. 2008). In turn, multi-actor participation strengthened and legitimized the MPAA. These two elements acted synergistically, with each one enabling the other (Fig. 1c).

Multi-actor participation was catalyzed by the MPAA through specific actions aimed at enlisting the support and participation of specific stakeholder groups. In an intensely developed context, such as the northern Mediterranean coastlines, recreational scuba divers and eco-tourists can become important key actors in shifting the tourism sector towards more responsible environmental practices. In the TPCC MPA, enlistment of scuba divers as allies of the MPAA has led to improved monitoring within the MPA, and to a level of control and enforcement of no-take regulations, particularly at the offshore sites, that would have been beyond the MPAA capacity. Scuba divers became not only key stakeholders but also allies that act as on-site informal wardens, thereby helping the MPA achieve its conservation goals. Similarly, granting local fishermen exclusive access privileges to designated zones within the MPA has created incentives for compliance and additional patrolling within the MPA, outside of the tourism season. While the effects of this action were not directly assessed for the TPCC MPA, a similar initiative was formally evaluated in the Torre Guaceto MPA in southern Italy, and was found to have produced significant ecological and economic benefits (Guidetti and Claudet 2010).

The TPCC MPAA is committed to further expanding the diffusion of its conservation vision through outreach and collaboration with stakeholders. Interviews identified the limited awareness and support of the MPA among local youth and entrepreneurs as key threats to the MPA. Thus, a recommendation from the SWOT analysis was to specifically target education of these categories of stakeholders (Appendix 8). In response to this suggestion, the MPAA has created a multimedia information center in the area of the main neighboring city that is most intensely visited by local youth, with the goal of increasing support for the MPA role and mission, and to support broader environmental education of the social component of this SES.

Based on the TPCC MPA case study, we propose a framework that summarizes the important organizational elements for how MPAAs may effectively mediate interactions between the ecological and socioeconomic components of the SES (Fig. 1c), and we identify key leverages that may most strongly influence MPA performance (indicated by the triangles, Fig. 4). We stress, however, that this framework is not prescriptive nor necessarily linear. Success may be achieved through different avenues, through a different sequence and combination of the stages we summarize in this framework, or through entirely different processes. Applying this framework to other systems requires its adaptation to local circumstances and conditions. In particular, institutions other than an MPAA may mediate social-ecological interactions in some settings.

The development trajectory of an MPA often begins with an original vision (Step 1 [S1], Fig. 4). A vision is the description of the future that we decide to create (Senge 2006). Other authors (Collins and Porras 1994, 1996) give a broader meaning to the concept of vision by including the core purpose and the core values of an organization. The original vision needs an enactor to become a reality. For example, the first $U$. S. National Parks, such as Yosemite or Yellowstone, originated from the vision of individuals like Frederick 
Fig. 4. Organizational framework for how marine protected area (MPA) authorities can effectively mediate interactions between social, economic, and ecological elements of social-ecological systems, based on key leverages (shown as triangles) (ESE: ecological and socioeconomic). The shaded numbers on the right-hand side refer to the different steps involved.

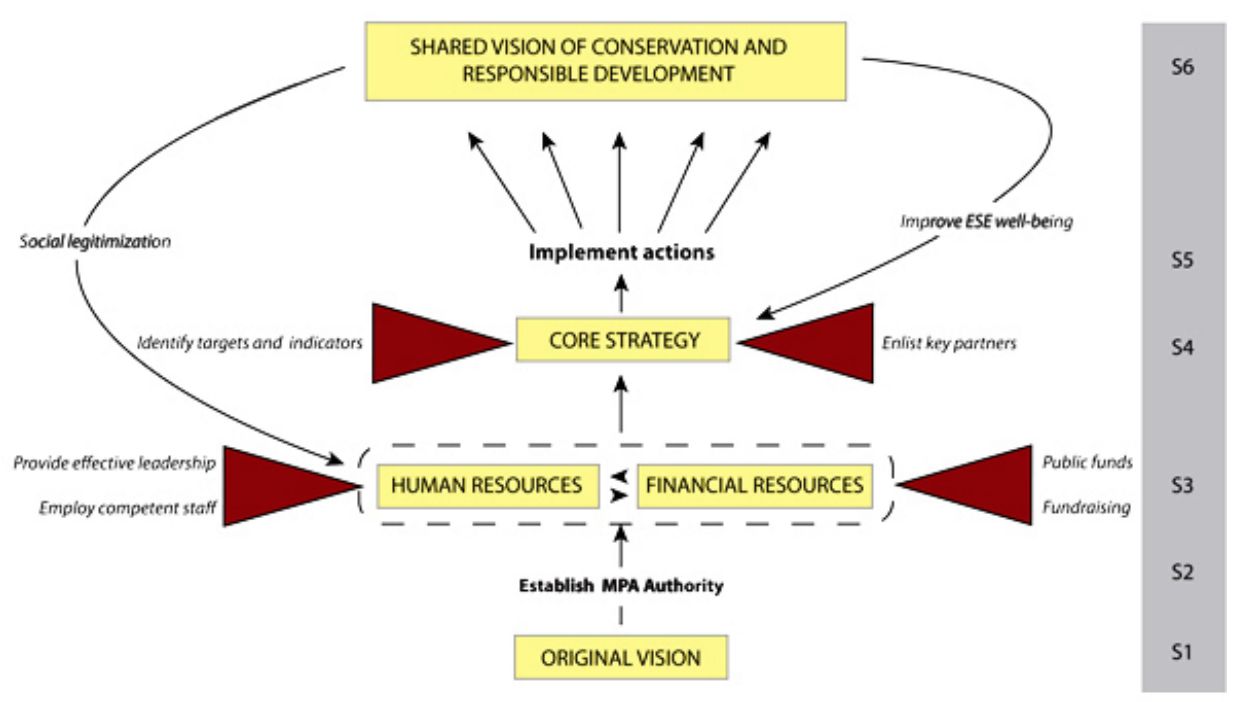

Hayden and John Muir. Similarly, MPA envisioners make significant efforts to establish protected areas and associated organizations with a coherent mission (S2, Fig. 4). The mission is the core purpose of an organization, the reason why an organization exists (Senge 2006). Protected areas are the most common public or nonprofit organizations with a clear mission to conserve nature and associated ecosystem services and cultural values (IUCN 2008). For example, the U.S. National Park Service was created with the explicit mission to "conserve natural and historical objects and the wildlife...for future generations" (United States Public Law 1916). Similarly, the MPAAs' mission is the long-term protection of the environment and associated services and cultural values (Kelleher 1999).

In order to function, and thus to achieve its conservation mission, the MPAA needs sufficient human and financial resources (S3, Fig. 4). Adequate resources are critical to the functioning of the MPAA and elements that can be acted upon to improve performance. To be effective, MPAAs need a permanent, competent staff and a substantial amount of financial resources. These resources are not available to most MPAAs, especially in the present economic crisis and in developing nations (Siikamaki 2011). Consequently, a critical leverage is an effective leadership that can act strategically on other elements. Specifically, a lack of public funds may be compensated for through fundraising with nongovernmental organizations, agencies, and private donors. Similarly, when an MPAA cannot hire competent permanent staff, carefully selected temporary staff and even volunteers can be highly effective.

With strong leadership and sufficient human and financial resources, the MPAA can develop a strategy for achieving a conservation and responsible development vision (S4, Fig. 4). The key leverages in developing an effective strategy are an identification of ecological and social targets of actions, and, as the next step, the successful involvement of partners to implement such actions. Key targets may include (1) the stakeholder groups that have an interest in the operation of the MPA and that significantly influence or are influenced by the ecosystem condition, and (2) the ecosystem components that the MPAA can influence through its management actions, or that can raise interest and catalyze the involvement of stakeholder groups (e.g., Fig. 3). Although the MPAA plays a unique role in activating the improvement process, it often has a small fraction of the needed resources to implement the required actions. To achieve positive change, the MPAA needs to enlist allies who participate in and support the strategic activities: users who, for cultural and/or economic reasons, share particular aspects of the MPAA vision. The MPAA can identify and plan specific strategies with each key partner category. These include monitoring and studies aimed at identifying priorities for management actions that can be designed and implemented in partnership with academic researchers, information campaigns with nongovernmental 
organizations, and ecotourism projects developed with the private sector.

As a result of the successful involvement of diverse partners and the implementation of strategic actions with each (S5, Fig. 4), the conservation and responsible development vision, originally formulated by one or few individuals, is now shared beyond the MPAA. Diverse actors collectively support and inform the core strategy initially developed by the MPAA, legitimize and therefore strengthen the organization itself, and contribute to improved social and ecological well-being within the SES (S6, Fig. 4).

Studies that have focused on successful examples of marine governance transformations in the Philippines (Alcala and Russ 2006), Australia (Olsson et al. 2008), Mexico (McCay et al., 2013), and Chile (Castilla 1999, Gelcich et al. 2010) have also highlighted key elements that underlie positive shifts. These include the presence of a window of opportunity for policy change that emerges from the failure of previous policies (Gelcich et al. 2010). However, enabling legislations, such as the establishment of MPAs, though essential, are not sufficient (Olsson et al. 2008). These case studies and our Mediterranean example show how strong but flexible institutions (e.g., the Great Barrier Reef and TPCC MPAAs, and the fishing communities and cooperatives of the Philippines, Mexican, and Chilean cases) are crucial in initiating transformation and providing leadership through the improvement process. Key steps include (1) the organization of functioning institutions, (2) increasing public awareness of the issues, and (3) an ability to involve a broader set of stakeholders. Another common element of these successful cases is (4) an effective incorporation of scientific knowledge and new insights, which both motivate policy change and guide the improvement process. Importantly, case studies highlighted to date suggest that successful models may be scalable from local (e.g., this study) to regional (e.g., Australia's Great Barrier Reef) extents.

One limitation of analysis of SESs is that controlled experiments do not exist. Outcomes are always the result of complex, context-dependent, and historically and culturally determined suites of interactions that cannot be dissected in simple ways. However, by analyzing multiple case studies, broadly distributed across different socioeconomic contexts and ecoregions, we can continue to build a collective understanding of the dynamics of complex SESs.

Multidisciplinary analyses have improved our understanding of MPA performance (e.g., Pomeroy et al. 2004, Pollnac and Pomeroy 2005, Hilborn 2007, McClanahan et al. 2011). In applying these results to support and inform effective future management of SESs, it is critical to focus on how key elements may interact, particularly how the presence of a specific leverage may trigger other positive outcomes. Institutions may be able to act upon these critical nodes and interactions to set the system on a trajectory towards improvement.

Comprehensive evaluations of SESs are therefore crucial for understanding what conditions can lead to success in marine management. As a recent example, Gutiérrez et al. (2011) used Ostrom's (2009) framework for the analysis of SESs to identify what attributes of community-based and comanaged fisheries correlate with their performance. This meta-analysis identified strong leadership as the most important factor that contributed to success, followed by individual or community quotas, social cohesion, and protected areas. In support of Gutiérrez et al.'s (2011) findings, our analysis of a highperforming Mediterranean MPA revealed that effective and competent leadership was the most critical element for ensuring sufficient resources and devising and implementing strategic plans with the participation of MPA allies. In the context of our work, the most relevant concepts of leadership view it as a critical factor in the interaction among diverse actors working to achieving specified objectives. Thus, leadership can be defined as a process of social influence where the leader seeks the voluntary participation of all potential partners in an effort to meet certain goals (Schriesheim et al. 1978).

In conclusion, we identify leadership and involvement of partners as key leverages that can set SESs on a pathway towards a high ecological, social, and economic performance, thereby enabling the shift from an original vision of a few individuals to a shared vision of conservation and responsible development. An important result of our analysis is that conservation success can be achieved even under challenging conditions, not only in remote areas characterized by low pressure on the ecosystems. By identifying what conditions and interactions underlie instances of success under pressure, we can focus on and invest in promoting and supporting these leverages in other systems. Continued analysis of successful cases and synthesis of insights into broader frameworks are crucial contributions to sustainability science, and to promoting marine governance and management transformations in practice.

Responses to this article can be read online at: http://www.ecologyandsociety.org/issues/responses. php/5799

\section{Acknowledgments:}

We are grateful to the Pew Charitable Trusts for financial support, K. Kroeker for preparing the graphics, M. Gomei and A. Navone for their insights and advice, S. Lee and C. Butner for reviewing earlier drafts, S. Cannicci, C. Volpi, D. Racano, D. Spigoli, B. Halpern, K. Selkoe, K. Kroeker, R. Martone, F. 
Bartolini, D. Marzo, and S. del Principe for participating in field studies, and two anonymous reviewers who provided invaluable feedback on earlier versions of this paper.

\section{LITERATURE CITED}

Abdulla, A., M. Gomei, E. Maison, and C. Piante. 2008. Status of marine protected areas in the Mediterranean Sea. IUCN Malaga and WWF France.

Airoldi, L., and M. W. Beck. 2007. Loss, status and trends for coastal marine habitats of Europe. Oceanography and Marine Biology: An Annual Review 45:345-405.

Alcala, A. C., and G. R. Russ. 2006. No-take marine reserves and reef fisheries management in the Philippines: a new people power revolution. Ambio 35:245-254. http://dx.doi. org/10.1579/05-A-054R1.1

Berkes, F., and C. Folke, editors. 1998. Linking social and ecological systems: management practices and social mechanisms for building resilience. Cambridge University Press, New York, New York, USA.

Carpenter, S. R., H. A. Mooney, J. Agard, D. Capistrano, R. S. DeFries, S. Diaz, T. Dietz, A. K. Duraiappah, A. OtengYeboah, H. M. Pereira, C. Perrings, W. V. Reid, J. Sarukhan, R. J. Scholes, and A. Whyte. 2009. Science for managing ecosystem services: beyond the Millennium Ecosystem Assessment. Proceedings of the National Academy of Sciences of the United States of America 106:1305-1312. http://dx.doi. org/10.1073/pnas.0808772106

Castilla, J. C. 1999. Coastal marine communities: trends and perspectives from human-exclusion experiments. Trends in Ecology \& Evolution 14:280-283. http://dx.doi.org/10.1016/ S0169-5347(99)01602-X

Ceccherelli, G., D. Casu, D. Pala, S. Pinna, and N. Sechi. 2006. Evaluating the effects of protection on two benthic habitats at Tavolara-Punta Coda Cavallo MPA (north-east Sardinia, Italy). Marine Environmental Research 61:171-185. http://dx. doi.org/10.1016/j.marenvres.2005.09.002

Cerrano, C., G. Bavestrello, C. N. Bianchi, R. Cattaneo-Vietti, S. Bava, C. Morganti, C. Morri, P. Picco, G. Sara, S. Schiaparelli, A. Siccardi, and F. Sponga. 2000. A catastrophic mass-mortality episode of gorgonians and other organisms in the Ligurian Sea (north-western Mediterranean), summer 1999. Ecology Letters 3:284-293. http://dx.doi.org/10.1046/ j.1461-0248.2000.00152.x

Christie, P., B. J. McCay, M. L. Miller, C. Lowe, A. T. White, R. Stoffle, D. L. Fluharty, L. T. McManus, R. Chuenpagdee, C. Pomeroy, D. O. Suman, B. G. Blount, D. Huppert, R. V. Eisma, E. G. Oracion, G. K. Lowry, and R. B. Pollnac. 2003. Toward developing a complete understanding: a social science research agenda for marine protected areas. Fisheries 28:2226.
Coll, M., C. Piroddi, C. Albuoy, F. Ben Rais Lasram, W. W. L. Cheung, V. Christensen, V. S. Karpouzi, F. Guilhaumon, D. Mouillot, M. Paleczny, M. L. Palomares, J. Steenbeek, P. Trujillo, R. Watson, and D. Pauly. 2011. The Mediterranean Sea under siege: spatial overlap between marine biodiversity, cumulative threats and marine reserves. Global Ecology and Biogeography 21:465-480. doi: 10.1111/j.1466-8238.2011.00697. $\mathrm{x}$ http://dx.doi.org/10.1111/j.1466-8238.2011.00697.x

Collins, J. C., and J. I. Porras. 1994. Built to last: successful habits of visionary companies. Harper Business, New York, New York, USA.

Collins, J. C., and J. I. Porras. 1996. Building your company's vision. Harvard Business Review 74:65-77.

Crowder, L. B., G. Osherenko, O. R. Young, S. Airame, E. A. Norse, N. Baron, J. C. Day, F. Douvere, C. N. Ehler, B. S. Halpern, S. J. Langdon, K. L. McLeod, J. C. Ogden, R. E. Peach, A. A. Rosenberg, and J. A. Wilson. 2006. Resolving mismatches in U.S. ocean governance. Science 313:617-618. http://dx.doi.org/10.1126/science.1129706

Di Franco, A., S. Bussotti, A. Navone, P. Panzalis, and P. Guidetti. 2009. Evaluating effects of total and partial restrictions to fishing on Mediterranean rocky-reef fish assemblages. Marine Ecology Progress Series 387:275-285. http://dx.doi.org/10.3354/meps08051

Ferretti, F., R. A. Myers, F. Serena, and H. K. Lotze. 2008. Loss of large predatory sharks from the Mediterranean Sea. Conservation Biology 22:952-964. http://dx.doi.org/10.1111/ j.1523-1739.2008.00938.x

Fox, H. E., C. S. Soltanoff, M. B. Mascia, K. M. Haisfield, A. V. Lombana, C. R. Pyke, and L. Wood. 2012. Explaining global patterns and trends in marine protected area (MPA) development. Marine Policy 36:1131-1138. http://dx.doi. org/10.1016/j.marpol.2012.02.007

Fraschetti, S., P. D’Ambrosio, F. Micheli, F. Pizzolante, S. Bussotti, and A. Terlizzi. 2009. Design of marine protected areas in a human-dominated seascape. Marine Ecology Progress Series 375:13-24. http://dx.doi.org/10.3354/ meps07781

Garrabou, J., R. Coma, N. Bensoussan, M. Bally, P. Chevaldonne, M. Cigliano, D. Diaz, J. G. Harmelin, M. C. Gambi, D. K. Kersting, J. B. Ledoux, C. Lejeusne, C. Linares, C. Marschal, T. Perez, M. Ribes, J. C. Romano, E. Serrano, N. Teixido, O. Torrents, M. Zabala, F. Zuberer, and C. Cerrano. 2009. Mass mortality in northwestern Mediterranean rocky benthic communities: effects of the 2003 heat wave. Global Change Biology 15:1090-1103. http://dx.doi. org/10.1111/j.1365-2486.2008.01823.x

Gelcich, S., T. P. Hughes, P. Olsson, C. Folke, O. Defeo, M. Fernandez, S. Foale, L. H. Gunderson, C. Rodriguez-Sickert, M. Scheffer, R. S. Steneck, and J.C. Castilla. 2010. Navigating 
transformations in governance of Chilean marine coastal resources. Proceedings of the National Academy of Sciences of the United States of America 107:16794-16799. http://dx. doi.org/10.1073/pnas.1012021107

Gell, F. R., and C. M. Roberts. 2003. Benefits beyond boundaries: the fishery effects of marine reserves. Trends in Ecology \& Evolution 18:448-455. http://dx.doi.org/10.1016/ S0169-5347(03)00189-7

Gerencser, M., R. Van Lee, F. Napolitano, and C. Kelly. 2008. Megacommunities. How leaders of government, business and non-profit can tackle global challenges together. Palgrave Macmillian.

Gordon, L. G., and E. I. Enfors. 2008. Land degradation, ecosystem services, and resilience of smallholder farmers in Makanya catchment, Tanzania. Pages 33-50 in D. Bossio and K. Geheb, editors. Conserving Land, Protecting Water. CABI, UK.

Graham, N. A. J., T. R. McClanahan, M. A. MacNeil, S. K. Wilson, N. V. C. Polunin, S. Jennings, P. Chabanet, S. Clark, M. D. Spalding, Y. Letourneur, L. Bigot, R. Galzin, M. C. Ohman, K. C. Garpe, A. J. Edwards, and C. R. C. Sheppard. 2008. Climate warming, marine protected areas and the oceanscale integrity of coral reef ecosystems. PLoS ONE 3(8): e3039. http://dx.doi.org/10.1371/journal.pone.0003039

Guerra, D. 2005. Superperformance. New profound knowledge of corporate leaders. Old Live Oak Books, Houston, Texas, USA.

Guidetti, P., S. Bussotti, P. Panzalis, S. Bava, E. Trainito, S. Vitale, C. Morri, R. Cattaneo-Vietti, A. Navone, and C. Nike Bianchi. 2007. Ecological and management implications of protecting Epinephelus marginatus at the Tavolara-Punta Coda Cavallo Marine Protected Area (NE Sardinia, Italy; western Mediterranean Sea). Pages 83-85 in P. Francour and J. Gratiot, editors. Second International Symposium on the Mediterranean Groupers. Nice University Publications, Nice, France.

Guidetti, P., and J. Claudet. 2010. Comanagement practices enhance fisheries in marine protected areas. Conservation Biology 24:312-318. http://dx.doi.org/10.1111/

j.1523-1739.2009.01358.x

Guidetti, P., M. Milazzo, S. Bussotti, A. Molinari, M. Murenu, A. Pais, N. Spano, R. Balzano, T. Agardy, and F. Boero. 2008. Italian marine reserve effectiveness: Does enforcement matter? Biological Conservation 141:699-709. http://dx.doi. org/http://dx.doi.org/10.1016/j.biocon.2007.12.013

Gutiérrez, N. L., R. Hilborn, and O. Defeo. 2011. Leadership, social capital and incentives promote successful fisheries. Nature 470:386-389. http://dx.doi.org/10.1038/nature09689
Halpern, B. S., S. Walbridge, K. A. Selkoe, C. V. Kappel, F. Micheli, C. D'Agrosa, J. F. Bruno, K. S. Casey, C. Ebert, H. E. Fox, R. Fujita, D. Heinemann, H. S. Lenihan, E. M. P. Madin, M. T. Perry, E. R. Selig, M. Spalding, R. Steneck, and R. Watson. 2008. A global map of human impact on marine ecosystems. Science 319:948-952. http://dx.doi.org/10.1126/ science. 1149345

Hilborn, R. 2007. Defining success in fisheries and conflicts in objectives. Marine Policy 31(2):153-158. http://dx.doi. org/10.1016/j.marpol.2006.05.014

Hilborn, R., J. M. Orensanz, and A. Parma. 2005. Institutions, incentives and the future of fisheries. Philosophical Transactions of the Royal Society B 360:47-57. http://dx.doi. org/10.1098/rstb.2004.1569

Hilborn, R., K. Stokes, J. J. Maguire, T. Smith, L. W. Botsford, M. Mangel, J. Orensanz, A. Parma, J. Rice, J. Bell, K. L. Cochrane, S. Garcia, S. J. Hall, G. P. Kirkwood, K. Sainsbury, G. Stefansson, and C. Walters. 2004. When can marine reserves improve fisheries management? Ocean \& Coastal Management 47:197-205. http://dx.doi.org/http://dx.doi. org/10.1016/j.ocecoaman.2004.04.001

Huete-Stauffer, C., I. Vielmini, M. Palma, A. Navone, P. Panzalis, L. Vezzulli, C. Misic, and C. Cerrano. 2011. Paramuricea clavata (Anthozoa, Octocorallia) loss in the Marine Protected Area of Tavolara (Sardinia, Italy) due to a mass mortality event. Marine Ecology 32:107-116. http://dx. doi.org/10.1111/j.1439-0485.2011.00429.x

International Union for Conservation of Nature (IUCN), World Commission on Protected Areas (WCPA). 2008. Guidelines for applying protected area management categories. Gland, Switzerland.

Jones, G. P., M. I. McCormick, M. Srinivasan, and J. V. Eagle. 2004. Coral decline threatens fish biodiversity in marine reserves. Proceedings of the National Academy of Sciences of the United States of America 101:8251-8253. http://dx.doi. org/10.1073/pnas.0401277101

Kelleher, G. 1999. Guidelines for Marine Protected Areas. IUCN, Gland, Switzerland and Cambridge, UK.

Lambin, E. F. 2005. Conditions for sustainability of humanenvironment systems: information, motivation, and capacity. Global Environmental Change 15:177-180. http://dx.doi. org/10.1016/j.gloenvcha.2005.06.002

Lejeusne, C., P. Chevaldonné, C. Pergent-Martini, C. F. Boudouresque, and T. Pérez. 2010. Climate change effects on a miniature ocean: the highly diverse, highly impacted Mediterranean Sea. Trends in Ecology \& Evolution 25:250 260. http://dx.doi.org/10.1016/j.tree.2009.10.009 
Lotze, H. K., H. S. Lenihan, B. J. Bourque, R. H. Bradbury, R. G. Cooke, M. C. Kay, S. M. Kidwell, M. X. Kirby, C. H. Peterson, and J. B. C. Jackson. 2006. Depletion, degradation, and recovery potential of estuaries and coastal seas. Science 312:1806-1809. http://dx.doi.org/10.1126/science.1128035

Mascia, M. B., C. A. Claus, and R. Naidoo. 2010. Impacts of Marine Protected Areas on fishing communities. Conservation Biology 24:1424-1429. http://dx.doi.org/10.1111/ j.1523-1739.2010.01523.X

McCay, B. J., and P. J. S. Jones. 2011. Marine Protected Areas and the governance of marine ecosystems and fisheries. Conservation Biology 25:1130-1133. http://dx.doi.org/10.1111/ j.1523-1739.2011.01771.x

McCay, B. J., F. Micheli, G. Ponce-Diáz, G. Murray, G. Shester, S. Ramirez-Sanchez, and W. Weisman. 2013. Cooperatives, concessions, and co-management on the Pacific Coast of Mexico. Marine Policy, in press. http://dx.doi. org/10.1016/j.marpol.2013.08.001

McClanahan, T. R., N. A. J. Graham, M. A. MacNeil, N. A. Muthiga, J. E. Cinner, J. H. Bruggemann, and S. K. Wilson. 2011. Critical thresholds and tangible targets for ecosystembased management of coral reef fisheries. Proceedings of the National Academy of Sciences of the United States of America 108:17230-17233. doi:10.1073/pnas.1106861108 http://dx. doi.org/10.1073/pnas.1106861108

McCook, L., T. Ayling, M. Cappo, J. H. Choat, R. D. Evans, D. M. De Freitas, M. Heupel, T. P. Hughes, G. P. Jones, B. Mapstone, H. Marsh, M. Mills, F. J. Molloy, C. R. Pitcher, R. L. Pressey, G. R. Russ, S. Sutton, H. Sweatman, R. Tobin, D. R. Wachenfeld, and D. H. Williamson. 2010. Adaptive management of the Great Barrier Reef: a globally significant demonstration of the benefits of networks of marine reserves. Proceedings of the National Academy of Sciences of the United States of America 107:18278-18285. http://dx.doi.org/10.1073/ pnas.0909335107

Micheli, F., B. S. Halpern, L. W. Botsford, and R. R. Warner. 2004. Trajectories and correlates of community change in notake marine reserves. Ecological Applications 14:1709-1723. http://dx.doi.org/10.1890/03-5260

Micheli, F., A. Saenz-Arroyo, A. Greenley, L. Vazquez, J. A. Espinoza Montes, M. Rossetto, and G. De Leo. 2012. Evidence that marine reserves enhance resilience to climatic impacts. PLoS ONE 7(7):e40832. doi:10.1371/journal.pone.0040832. http://dx.doi.org/10.1371/journal.pone.0040832.

Millennium Ecosystem Assessment. 2005. Ecosystems and human well-being health synthesis. Island Press, Washington D.C., USA.

Milne, G. R., E. S. Iyer, and S. Gooding-Williams. 1996. Environmental organization alliance relationships within and across nonprofit, business, and government sectors. Journal of Public Policy and Marketing 15:203-215.

Molnar, J. L., R. L. Gamboa, C. Revenga, and M. D. Spalding. 2008. Assessing the global threat of invasive species to marine biodiversity. Frontiers in Ecology and the Environment 6:485-492. http://dx.doi.org/10.1890/070064

Mora, C., and P. Sale. 2011. Ongoing global biodiversity loss and the need to move beyond protected areas: a review of the technical and practical shortcoming of protected areas on land and sea. Marine Ecology Progress Series 434:251-266. http:// dx.doi.org/10.3354/meps09214

Niccolini, F., and S. Del Principe. 2008. Verso una vision saggia dello sviluppo. Pages 264-269 in A. Navone and E. Trainito, editors. Tavolara. Carlo Delfino Editore, Sassari, Italy.

Niccolini, F., and D. Marzo. 2009. Turismo naturalistico e sviluppo responsabile. Dal valore delle specie simbolo alla strategia di conservazione sistemica. Il caso della cernia bruna dell'Area Marina Protetta di Tavolara Punta Coda Cavallo. Report to the TPCC MPAA.

Olsson, P., C. Folke, and T. P. Hughes. 2008. Navigating the transition to ecosystem-based management of the Great Barrier Reef, Australia. Proceedings of the National Academy of Sciences of the United States of America 105:9489-9494. http://dx.doi.org/10.1073/pnas.0706905105

Osborne, D., and T. Gaebler, 1992. Reinventing government. Addison-Wesley, Boston, Massachusetts, USA.

Ostrom, E. 2005. Understanding institutional diversity. Princeton University Press, Princeton, New Jersey, USA.

Ostrom, E. 2009. A general framework for analyzing sustainability of social-ecological systems. Science 325:419422. http://dx.doi.org/10.1126/science.1172133

Pollnac, R. B., and R. S. Pomeroy. 2005. Factors influencing the sustainability of integrated coastal management projects in the Philippines and Indonesia. Ocean \& Coastal Management 48:233-251. http://dx.doi.org/10.1016/j.

ocecoaman.2005.04.003

Pomeroy, R. S., J. E. Parks, and L. M. Watson. 2004. How is your MPA doing? A guidebook of natural and social indicators for evaluating Marine Protected Area management effectiveness. IUCN, WWF, Gland, Switzerland and NOAA, Gland Switzerland and Cambridge, UK. http://dx.doi. org/10.2305/IUCN.CH.2004.PAPS.1.en

Sala, E., E. Ballesteros, P. Dendrinos, A. Di Franco, F. Ferretti, D. Foley, S. Fraschetti, A. Friedlander, J. Garrabou, H. Güçlüsoy, P. Guidetti, B. S. Halpern, B. Hereu, A. A. Karamanlidis, Z. Kizilkaya, E. Macpherson, L. Mangialajo, S. Mariani, F. Micheli, A. Pais, K. Riser, A. Rosenberg, M. 
Sales, K. A. Selkoe, R. Starr, F. Tomas, and M. Zabala. 2012. The structure of Mediterranean rocky reef ecosystems across environmental and human gradients, and conservation implications. PLoS ONE 7(2):e32742. doi:10.1371/journal. pone.0032742 http://dx.doi.org/10.1371/journal.pone.0032742

Schriesheim, C. A., J. M. Tolliver, and O. C. Behling. 1978. Leadership theory: some implications for managers. MSU Business Topics, Summer 1978:35.

Senge, P. 2006. The fifth discipline. Random House, London, UK.

Siikamaki, J. 2011. Contributions of the U.S. State Park System to nature recreation. Proceedings of the National Academy of Sciences of the United States of America 108:14031-14036. http://dx.doi.org/10.1073/pnas.1108688108

Stevenson C., L. Katz, F. Micheli, B. Block, K. Heiman, C. Perle, K. Weng, R. Dunbar, and J. Witting. 2007. High apex predator biomass on remote Pacific islands. Coral Reefs 26:47-51. http://dx.doi.org/10.1007/s00338-006-0158-x

United States Public Law. 1916. Act to Establish a National Park Service and for Other Purposes. (16 U.S.C. 1 et seq. (1988), Aug. 25, 1916, ch. 408, 39 Stat. 535)

Worm, B., E. Barbier, N. Beaumont, J. E. Duffy, C. Folke, B. S. Halpern, J. B. C. Jackson, H. K. Lotze, F. Micheli, S. Palumbi, E. Sala, K. A. Selkoe, J. J. Stachowicz, and R. Watson. 2006. Impacts of biodiversity loss on ocean ecosystem services. Science 314:787-790. http://dx.doi. org/10.1126/science. 1132294 
Appendix 1. Questions included in the surveys used to interview different stakeholder categories (see Table 1). Selected examples are included. Below we report questions that were common to all surveys (highlighted in blue) and those that were asked to specific stakeholder groups.

\section{Every stakeholder category}

\section{Personal Information ${ }^{1}$}

+ Age (under 10, 11-20, 21-30, 31-40, 41-50, 51-60, 61-70, over 70)

\section{+ Gender $\quad(M$ or $F)$}

+ Education level (Elementary School, Middle School, High School, Bachelor's or Master's degree or PhD)

+ Occupation (Entrepreneur, Unemployed By Choice, Manager -Public or Private Sector, Army/Police, Teacher-Professor - Researcher,

Clerk/Factory Worker, Retired, Student, Unemployed, other - specify)

\section{Marine Protected Area knowledge}

+ Are you aware of the fact that an MPA has been created that includes the islands of Tavolara, Molara, Molarotto and the coast between Capo Ceraso and Cala Finocchio? (Yes or No)

+ How did you learn about it? (Friends or acquaintances, information offices, the Port Authorities, the MPA authority, newspapers, TV, radio, signs and road markings, other - specify)

\section{Sensitivity to and orientation toward the goals of protected areas}

+ Some municipalities of nearby Corsica asked to be included in the nature park, knowing they would not receive any additional funding. In your opinion, what might the reasons be for this choice? (more tourism in shoulder seasons, "more desirable" tourists (more educated and respectful of the environment), to ensure a future for younger generations, a clean and healthy environment, greater quantity and quality of fish caught after several years, the possibility of converting fishing activities into more profitable activities (fishing tourism). (Definitely yes, probably yes, probably not, definitely not)

\section{$\underline{\text { All key entrepreneur segments and key informants }}$}

\footnotetext{
1 The questions highlighted in light blue were used in short interviews.
} 


\section{General open questions}

+ In your opinion, what are the major economic and social problems in the area?

+ What advice would you give to improve management of this area?

\section{All key entrepreneur segments}

\section{Environmental perception}

In your opinion, how and by how much do you think these factors have influenced the local coasts and sea? Fish poaching,Tourism development, Port activities, Industrial activities, Use of pesticides in agriculture, Lack of supervision. (Type of impact: Positive, Negative, Irrelevant. Intensity of impact: High, Medium, Low.)

\section{All key entrepreneur segments except fishermen}

\section{Firm size and managerial composition}

+ Who manages the firm? (The owner, The owner and its family, The owner and one or more managers, One or more managers. Please indicate if these people live permanently in Sardinia or not.)

+ Human resources composition in the last two years. (Total number of employees, of which: No. of managers, No. of office employees, No. of skilled laborers. Please specify how many are university graduates and how many live permanently in Sardinia.)

\section{Expectations regarding the TPCC MPA}

What role might the TPCC MPA play in order to improve the situation of your firm?

\section{Certifications}

+ With reference to environmental quality or sustainable tourism certifications, has your company (Already obtained one, Would like to obtain one, but do not have the time or the skills to do it, Believes it is a useless tool).

IT use

Does the company have a web site? (Yes, No) If yes, can you conduct e-commerce? (Yes, No) 


\section{Real ${ }^{2}$ Seasonality}

+ What is the seasonal distribution of your customers? (Percentage in each month: Jan. Feb. Mar. Apr. May. June. Jul. Aug. Sept. Oct. Nov. Dec)

\section{Customer distribution}

+ What is the distribution of customers by their region of origin (percentage for each region: Sardinian, Italian except Sardinian, Foreign)

\section{Income relevance}

What is the contribution of the firm's income to the total family income (please specify the percentage)?

\section{Local retention of added value}

Please indicate the origin of your supplies (Percentage by area: Local=county, Regional, Italian, Foreign).

\section{Awareness and sharedness of the MPA's mission}

+ With respect to the following statement: "If we do not conserve the coast and the sea, with regulations and prohibitions as well, sites will progressively lose their charm and their attractiveness to tourists, and the socio-economic situation will eventually worsen," do you: (Completely agree, mostly agree, mostly disagree, completely disagree)

+ With respect to the following statement: "A protected area is an asset for future generations", do you: (Completely agree, mostly agree, mostly disagree, completely disagree)

\section{Networking approach}

+ What are the organizations with whom you collaborate most frequently? (Tour operators, Travel agencies, Hotels and residences, others.)

+ Where are they located? (Inside MPA municipalities' boundaries, Outside MPA municipalities' boundaries)

\section{Fishermen}

\footnotetext{
2 This question was introduced since levels of seasonality reported in local statistics (official municipality data) were significantly different (lower) than those deriving from empirical observations.
} 


\section{Awareness and sharedness of the MPA's mission}

+ With respect to the following statement: "If we do not manage the sea well, with regulations and prohibitions as well, the fish available for our children and future generations will progressively decrease" do you: (Completely agree, mostly agree, mostly disagree, completely disagree)

\section{MPA perceived effects}

+ After establishment of the MPA, did you experience more advantages or more constraints? (More constraints, More or less the same, More advantages)

+ Can you please specify the most relevant advantages and constraints?

+ The quantity of fish caught has (Increased, Decreased, Is more or less the same).

+ The quality of fish caught has (Increased, Decreased, Is more or less the same).

\section{Fishing techniques}

+ Which fishing methods do you normally use?

+ Who taught you the "art of fishing"?

\section{Socio-environmental perception}

+ In your opinion, how strong has the impact of the following fishing methods been on underwater marine life? Spearfishing, Fishing with explosives, Trawling (Intensity of the impact: Very High, High, Medium, Low, No impact)

\section{Local retention of added value}

+ To whom do you usually sell the fish? (Please indicate the average percentage of sales to each category) (Local restaurants, Local fish market, Tourists, Dealers who sell the fish outside the region, Other-specify.)

\section{Characteristics of the fishing activity}

+ With how many other people do you go fishing? (Another person, Two, Three, More than three people.)

+ Is the fishing equipment yours? (Yes, No) If not, who owns it? Who made it? Who repairs it? 


\section{Potential demand for alternative/associated lower-impact activities}

+ Do any tourists ask you to do boat tours? (Yes, No)

+ Do any tourists ask to go fishing with you? (Yes, No)

+ Do any tourists ask you information about local flora and fauna? (Yes, No)

\section{Relationship with the MPA Authority}

+ How is your relationship with the MPA authority? (Bad, Acceptable, Good, Excellent)

+ Do MPA regulations respect local fishing traditions? (Yes, No)

+ What traditions are respected or not?

\section{Interactions with marine mammals}

+ Have marine mammals (such as dolphins) ever damaged your fishing tools (nets, etc.)? (Yes, No)

+ In your opinion, what options would be suitable to address this kind of damage? (Kill the animals, Receive compensation for damage, Convert the fishing activity to a tourism-oriented one, such as fishing tourism, Other.)

\section{Fishing dynamics and possible sightings of rare endangered species}

+ What do you think about the state of conservation of these animals compared with 30 years ago? Groupers, Lobsters, Sea Breams, Dolphins, Monk seals, Turtles, European shag.) (Worse, The same, Better, Much better.) Can you please specify the year you last saw it?

If a monk seal was seen: will you please sign this statement?

\section{Income relevance}

What is the percentage of fishing income relative to the total family income? (Please specify the percentage.)

\section{$\underline{\text { Key informants }}$}

+ What kind of activities could local public authorities (MPA, Municipalities, Counties, and the Sardinia Region) undertake to improve the situation in your territory?

+What role might the TPCC MPA play in order to improve the local situation? 
+ Do you think the TPCC MPA is a stimulus or an obstacle to the economic and social development of the area? Why?

+ Which factors do you think have influenced and are influencing the natural environment most significantly?

+ (For negative changes) What major changes in the natural environment are connected to these threats?

+ What are the most beautiful things that make living in this area worthwhile?

+ What are the most beautiful things in this area that could be better used as tourist attractions?

+ What are the lesser-known local traditions that could be used as tourist attractions?

\section{$\underline{\text { Teachers }}$}

+ What are the major problems suffered by young people who are the age of your students?

+ Are environmental education programs taught in your class? (Yes, No.)

+ If yes, what kinds of environmental education programs are taught in your class?

+ How much are kids/children interested in environmental education lessons?

(Extremely, Very, Enough, A little, Not at all.)

+ In your opinion, do families build upon the environmental education programs in everyday life?

\section{$\underline{\text { Every tourist segment }}$}

\section{General information}

\section{+ Where is your place of residence? (City and State)}

+ Please indicate the duration of your holiday in Sardinia? (Days)

+ How many hours do you spend every day in the MPA? (on the beach...)

\section{Tourist loyalty}

+ How many times have you been to this area before? (First time, Second time, Two other times, More than twice, More than 5 times, More than 10 times.) 
+ How many times have you been in Sardinia before? (First time, Second time, Two other times, More than twice, More than 5 times, More than 10 times.)

\section{Global customer satisfaction}

+ Would you like to vacation in this area again?

+ Would you like to vacation in Sardinia again?

+ Would you recommend visiting Tavolara Punta Coda Cavallo Marine Protected Area (hereafter TPCC MPA) to your relatives and/or friends? (Yes or No.)

\section{Ecotourism experience}

+ Have you ever visited other MPAs? (Yes or No.) If yes, which one?

+ Which of these activities would you like to $\mathrm{do}^{3}$ ? (Guided nature walks to learn about local flora and fauna, Diving or snorkeling, Boat tours, Non-motorized water sports (sailing, windsurfing), Visits to aquariums, Inland visits, Outdoor nature-compatible sports (hiking, biking, jogging), Thematic tours, Summer camps, Other (specify).)

If you won a free vacation in one of the following locations, which would you choose? (Rimini, Ustica, Port-cros, Nice, Island of Monte Cristo, Porto Cervo, Island of Lavezzi ${ }^{4}$.)

\section{Satisfaction with key MPA services}

+ How would you evaluate the quality of these services within the MPA boundaries (Enforcement, Information, Informational signs, Outdoor activities and hiking tours)? Please list and comment on specific deficiencies. (Very bad, Poor, Sufficient, Good, Very good.)

\section{Evaluation of the quality of environment and services}

+ How do you evaluate the quality of these aspects/services: Landscape, Beaches and coasts, Air, Green areas, Villages, Hospitality, Traffic, Restaurants, Accommodation, Noise, Leisure and entertainment, Security, Prices? (Very bad, Poor, Sufficient, Good, Very good.)

\footnotetext{
${ }^{3}$ For this and subsequent questions, the alternatives indicated have been submitted to beach tourists. Some differences in the alternatives occurred between the three key tourism segments.

${ }^{4}$ All of these locations are exemplary for some particular tourism segment: mass tourism (Rimini and Nice), luxury tourism (Porto Cervo), ecotourism (Lavezzi and Ustica), wilderness tourism (Island of Monte Cristo).
} 
+ How do you evaluate the quality of these aspects/services related to the beach experience: Sea water, Beach cleanliness, Beach equipment, Lifeguard monitoring, Toilets, Crowding, Manners of water-sports practitioners (surfers, jet-skiers, etc.) (Very bad, Poor, Sufficient, Good, Very good.)

\section{Accessibility evaluation 5}

+ How would you rate these aspects: Parking availability, Parking costs, Police, Bus, Taxi, Pier operation, Ferry operation, Cost of the ferry, Olbia Airport, Airfares? (Very bad, Poor, Sufficient, Good, Very good.)

\section{Perception of MPA's value and expectations}

+ Protected areas offer opportunities and imply some constraints. Which is more relevant in your opinion? (More constraints, More or less the same, More opportunities.)

+ The number of MPAs is increasing all over the world. What do you expect from an MPA? (Wilderness and uncontaminated nature, More opportunities to view wildlife, Beautiful and tranquil beaches, People and signs that explain the natural heritage of the area, including flora and fauna, The possibility to practice environmentally compatible outdoor sports, Guided boat trips, Few environmental problems caused by boats and vessels in the vicinity of the coast, Enforcement, Fishing tourism)

\section{Expectations for the TPCC area}

+ Looking at the local situation, what factors would encourage you to spend a vacation again, or for longer periods, in this place? (Lower prices for accommodation, Improved infrastructure, e.g., roads, Improved wilderness and less contaminated nature, More opportunities to view wildlife, More tranquility on the beaches, More people and posters to explain the natural heritage of area, including flora and fauna, More possibilities to practice environmentally compatible outdoor sports, More opportunities for guided boat trips, Fewer problems caused by boats in the vicinity of coasts,

More enforcement, Other.)

\section{Willingness to pay}

+ Would you be willing to pay an additional price to safeguard this heritage or to receive environmental or educational services here? (Yes or No). If yes, how much? (1-2€, 3-5€, 6-10€, more than $10 €)$

\section{Expenditure}

5 This question has not been submitted to the sailing segment. 
Approximately how much have you (if with family: and your family) spent for this holiday on the following items? Accommodation, Travel, Meals, Other purchases

\section{For beach tourists and scuba diving segments}

\section{Accommodations $^{6}$}

\section{+ Where are you staying in Sardinia? (municipality)?}

+ Which kind of accommodations did you choose for your stay? (Friend's house, Hotel, Agri-tourism, Residence, B\&B, Camping, House for rent, Second home ownership, Camper, Boat, Resident)

+How would you rate your accommodations on the following aspects? Globally, Price, Booking services. (Really bad, Poor, Sufficient, Good, Very good).

\section{$\underline{\text { Scuba divers }}$}

+ How do you rate the quality of the marine ecosystems of the TPCC MPA? (Bad, Adequate, Good, Excellent).

+ Where are the best diving sites in the TPCC MPA?

+ Do you think it is important to establish diving areas where fishing is prohibited any form? (Yes or No).

+ Which level of scuba diving licence do you have? $\left(1^{\text {st }}, 2^{\text {nd }}, 3^{\text {rd }}\right.$, up to $3^{\text {rd }}$ level)

+ Have you already gone on dives in TPCC MPA? (Yes: How many times in the current year? Yes: how many times last year? No. This was the first experience)

+What is the main reason that made you choose to dive in the TPCC MPA? (Just for fun, I don't go diving so frequently, Passion, Diving is my hobby, Beauty of the depths and underwater wildlife, Presence of marine species of special interest - grouper, sea bream, eels, etc. -, other specify).

6 This section has not been submitted to the sailing segment 
Appendix 2. Stakeholder categories interviewed. The number of interviews conducted with each group is reported.

\begin{tabular}{|c|c|c|}
\hline & $\begin{array}{l}\text { Short } \\
\text { interviews }\end{array}$ & $\begin{array}{l}\text { In-depth } \\
\text { interviews }\end{array}$ \\
\hline Key stakeholders, comprising: & 239 total & 134 total \\
\hline Key informants & & 13 \\
\hline Key entrepreneurs: & & 18 \\
\hline Fisherman & & 9 \\
\hline Scuba diving centers & & 9 \\
\hline Key tourists: & 239 & 106 \\
\hline Scuba divers & 73 & 60 \\
\hline Sailors & 166 & 46 \\
\hline Relevant stakeholders, comprising: & 2595 total & 241 total \\
\hline Relevant entrepreneurs: & & 57 \\
\hline Boat Renting & & 8 \\
\hline Hotel and Restaurant & & 23 \\
\hline Commerce and Services & & 26 \\
\hline Relevant tourists (beach tourists) & 2595 & 184 \\
\hline
\end{tabular}


Appendix 3. Examples of interpretation of results. Appendix 3a reports a summary of answers to the question "If you won a free vacation in one of the following locations, which one would you choose?". To calculate the indicators listed as " $4 \mathrm{I} D 4$ " and "4 4 I 4 " in Appendix 4: "Eco (and wilderness) tourism motivation or orientation of key (scuba) and relevant (beach) tourists", we calculated the percent responses indicative of a preference for the type of tourism that each location represents (Appendix 3b). Color coding indicates the correspondence of each location (Appendix 3a) with the type of tourism preferred (Appendix 3b).

a.

\begin{tabular}{|c|c|c|c|c|c|c|}
\hline \multirow[t]{2}{*}{ LOCATION } & \multicolumn{3}{|c|}{$\begin{array}{l}\text { Key stakeholder } \\
\text { (Scuba divers) }\end{array}$} & \multicolumn{3}{|c|}{$\begin{array}{l}\text { Relevant stakeholder } \\
\text { (Beach tourists) }\end{array}$} \\
\hline & Tot. & $\%$ & $\begin{array}{l}\text { Answer } \\
\text { rate }\end{array}$ & & & $\begin{array}{l}\text { Answer } \\
\text { rate }\end{array}$ \\
\hline USTICA (MPA) & 21 & $33 \%$ & \multirow[t]{7}{*}{$100 \%$} & 31 & $15 \%$ & \multirow[t]{7}{*}{$76 \%$} \\
\hline LAVEZZI (MPA) & 16 & $25 \%$ & & 54 & $27 \%$ & \\
\hline $\begin{array}{l}\text { ISLAND OF MONTE CRISTO (STRICT } \\
\text { WILDERNESS RESERVE, NO } \\
\text { DEVELOPMENT) }\end{array}$ & 11 & $17 \%$ & & 31 & $15 \%$ & \\
\hline PORTO CERVO & 10 & $16 \%$ & & 52 & $26 \%$ & \\
\hline PORT-CROS (MPA) & 4 & $6 \%$ & & 12 & $6 \%$ & \\
\hline RIMINI & 1 & $2 \%$ & & 5 & $3 \%$ & \\
\hline NIZZA & 1 & $2 \%$ & & 17 & $8 \%$ & \\
\hline
\end{tabular}

b.

\begin{tabular}{|c|c|c|c|c|}
\hline \multirow{2}{*}{$\begin{array}{l}\text { INTERPRETATION of the answers } \\
\text { (eco-motivation of the tourists) }\end{array}$} & \multicolumn{2}{|c|}{ Scuba divers } & \multicolumn{2}{|c|}{ Beach tourists } \\
\hline & Total & $\%$ & Total & $\%$ \\
\hline MPA Eco-tourism & 41 & $64.0 \%$ & 97 & $48.0 \%$ \\
\hline Strict wilderness tourism & 11 & $17.2 \%$ & 31 & $15.3 \%$ \\
\hline Luxury tourism & 11 & $17.2 \%$ & 69 & $34.2 \%$ \\
\hline Mass tourism & 1 & $1.6 \%$ & 5 & $3 \%$ \\
\hline
\end{tabular}


Appendix 4. Selected socioeconomic and cultural indicators. Indicators that are not highlighted with any colour in the second column were collated and calculated from documents, i.e., official statistics from the Italian National Institute of Statistics (ISTAT), publications deriving from previous research on the economy and society in the area of interest (for example, CRENOS, Economia del turismo in Sardegna, CUEC, Cagliari, 2004;

BANCO DI SARDEGNA, L'economia del Nord Est Sardegna, Eurografica, Olbia, 2004). Data on criminality and drugs (IC and ID) were obtained from the Statistics Office at the Sassari Police Department. Data on the seasonality of the arrival flux (IIIC2) came from the Olbia Port Authorities and the Olbia Costa Smeralda Airport Management Society.

The indicators highlighted in the second column in yellow, pertaining to the analysis of the enterprises, were calculated in the following way: first, identification of the "documented enterprises population" was made from Chamber of Commerce registrations. Second, the "real enterprises population" was obtained from the documented population (documental data differ from "real" data due to various activity codes registered by entrepreneurs that are "broader" than the activity usually undertaken) via a census test, in which the tabulations of the Chamber of Commerce were shown to people familiar with the activity performed, such as the local policemen.

The indicators highlighted in light blue were obtained through interviews conducted with the stakeholders.

\begin{tabular}{|c|c|c|c|c|c|c|c|}
\hline \multirow[t]{3}{*}{ Category } & \multirow[t]{3}{*}{ Indicator } & \multirow[t]{3}{*}{ Measures } & $\begin{array}{c}\text { LPS } \\
\text { (Core } \\
\text { Munic. } \\
\text { 1) }\end{array}$ & $\begin{array}{c}\text { ST } \\
\text { Core } \\
\text { Munic. } \\
\text { 2) }\end{array}$ & $\begin{array}{c}\text { LS } \\
\text { Avg } \\
\text { (Core } \\
\text { area } \\
\text { Avrg.) }\end{array}$ & $O L$. & $\begin{array}{l}\text { TotalA } \\
\text { vg. }\end{array}$ \\
\hline & & & \multicolumn{5}{|c|}{ Recorded value } \\
\hline & & & \multicolumn{5}{|c|}{ Previous condition (eventual) } \\
\hline \multicolumn{8}{|c|}{ 1) Society } \\
\hline \multirow{11}{*}{$\begin{array}{l}\text { 1A) Demographic } \\
\text { structure }\end{array}$} & \multirow{2}{*}{ 1) Resident population } & \multirow{2}{*}{$\begin{array}{l}\text { No. of residents } \\
\text { (comparison 2001-2005) }\end{array}$} & 2508 & 3565 & 6073 & 48200 & 54.273 \\
\hline & & & 2214 & 3103 & 5317 & 45366 & 50.683 \\
\hline & 1') Population dynamics & $\begin{array}{l}\text { Demographic balance (2001-2005) } \\
\text { Average annual rate of increase ('01-'05) }\end{array}$ & $\begin{array}{c}294 \\
3.17 \%\end{array}$ & $\begin{array}{c}462 \\
3.53 \%\end{array}$ & $\begin{array}{l}378 \\
3.38 \%\end{array}$ & $\begin{array}{l}2834 \\
1.53 \%\end{array}$ & $\begin{array}{c}3590 \\
1.73 \%\end{array}$ \\
\hline & \multirow{2}{*}{ 2) Population density } & \multirow{2}{*}{$\begin{array}{l}\text { No. of inhabitants per } \mathrm{km}^{2} \\
\text { (comparison 2001-2005) }\end{array}$} & 21.3 & 34.0 & 27.6 & 128.2 & 90.6 \\
\hline & & & 18.8 & 29.6 & 24.2 & 120.6 & 84.7 \\
\hline & 3) Family structure & No. of families (2001) & 819 & 1035 & 1854 & 14647 & 16501 \\
\hline & $\begin{array}{l}\text { 3') Average size of } \\
\text { households }\end{array}$ & Total population / No. of families (2001) & 2.7 & 3.0 & 2.9 & 3.1 & 3.1 \\
\hline & 3") Family stability & No. of divorced* 100 / No. of married (2005) & $1.9 \%$ & $2.1 \%$ & $2.0 \%$ & $3.1 \%$ & $2.9 \%$ \\
\hline & \multirow{2}{*}{ 4) Old age rate } & \multirow{2}{*}{$>65$ years / 0-14 years $(2001-2005)$} & 1.386 & 0.966 & 1.118 & 0.790 & 0.824 \\
\hline & & & 1.146 & 0.912 & & 0.698 & \\
\hline & 5) Migratory balance & Residents registrations - cancellations (2001) & +48 & +73 & +121 & +284 & +405 \\
\hline
\end{tabular}




\begin{tabular}{|c|c|c|c|c|c|c|c|}
\hline & & $\begin{array}{l}\text { Residents registrations - cancellations / Total } \\
\text { population* } 100(2001)\end{array}$ & $+2.17 \%$ & $+2.35 \%$ & $+2.28 \%$ & $+0.63 \%$ & $+0.80 \%$ \\
\hline \multirow{5}{*}{$\begin{array}{l}\text { 1A') Educational } \\
\text { potential }\end{array}$} & 1) Educational potential & $\%$ of population between 2 and 17 years & & & & & $15.8 \%$ \\
\hline & 2) Childhood educ. potential & $\%$ of population between 2 and 5 years & & & & & $3.9 \%$ \\
\hline & $\begin{array}{l}\text { 3) Elementary school } \\
\text { educational potential }\end{array}$ & $\%$ of population between 6 and 10 years & & & & & $4.6 \%$ \\
\hline & 4) Middle school educ. pot. & $\%$ of population between 11 and 14 years & & & & & $4.1 \%$ \\
\hline & 5) High school educ. pot & $\%$ of population between 15 and 17 years & & & & & $3.1 \%$ \\
\hline \multirow{3}{*}{ 1B) Occupation } & 1) Unemployment rate & No. of unemployed * 100 / Total pop. (2001) & $18.6 \%$ & $17.5 \%$ & & $21.3 \%$ & \\
\hline & \multirow[b]{2}{*}{$\begin{array}{l}\text { 2) Population dependency } \\
\text { ratio }\end{array}$} & \multirow{2}{*}{$\begin{array}{l}\text { Not in working-age population (age between } 0 \text { and } \\
14 \text { and over } 65 \text { ) / Potentially working population } \\
\text { (age between } 15 \text { and } 64 \text { years) (comparison } 2001 \text { - } \\
2005 \text { ) }\end{array}$} & 0.405 & 0.419 & 0.413 & 0.356 & 0.362 \\
\hline & & & 0.412 & 0.388 & & 0.349 & \\
\hline \multirow{6}{*}{ 1C) Drug diffusion } & \multirow[b]{2}{*}{ 1) Drug diffusion } & No. of reports for drug reasons (Avg. 2004-2005) & 2 & & & 91 & \\
\hline & & $\begin{array}{l}\text { No. of people stopped or jailed by police because } \\
\text { of drugs (Average 2004-2005) }\end{array}$ & 1.5 & & & 33.5 & \\
\hline & \multirow{2}{*}{ 2) Drug dealing and selling } & $\begin{array}{l}\text { No. of people reported by police because of drug } \\
\text { dealing/selling (Average 2004-2005) }\end{array}$ & 1.5 & & & 23 & \\
\hline & & $\begin{array}{l}\text { No. of people stopped or jailed by police because } \\
\text { of drug dealing/selling (Avg. 2004-2005) }\end{array}$ & 1.5 & & & 17 & \\
\hline & \multirow{2}{*}{ 3) Drug production } & $\begin{array}{l}\text { No. of people reported by police because of drug } \\
\text { production (Average 2004-2005) }\end{array}$ & 0 & & & 11 & \\
\hline & & $\begin{array}{l}\text { No. of people stopped or jailed by police because } \\
\text { of drug production (Avg. 2004-2005) }\end{array}$ & 0 & & & 10 & \\
\hline \multirow{8}{*}{ 1D) Criminality } & \multirow{2}{*}{ 1) Minor (lower) criminality } & \multirow{2}{*}{$\begin{array}{l}\text { No. of reports of theft } \\
\text { (Avg. 2004-05 and Avg. 2002-2003) }\end{array}$} & 93 & & & 452 & \\
\hline & & & & & & 373 & \\
\hline & \multirow{2}{*}{ 2) Major (serious) criminality } & \multirow{2}{*}{$\begin{array}{l}\text { No. of attempts and robberies } \\
\text { (Avg. 2004-05 and Avg. 2002-2003) }\end{array}$} & $0 ; 1$ & & & $12 ; 15$ & \\
\hline & & & & & & $0 ; 5$ & \\
\hline & \multirow{2}{*}{ 3) Overall criminality } & \multirow{2}{*}{$\begin{array}{l}\text { No. of arrests; No. of people reported but not } \\
\text { jailed (Avg. 2004-05 and Avg. 2002-2003) }\end{array}$} & $4.5 ; 22$ & & & 54,304 & \\
\hline & & & & & & $29 ; 235$ & \\
\hline & \multirow{2}{*}{ 4) Young age criminality } & \multirow{2}{*}{$\begin{array}{l}\text { Number of people reported under the age of } 18 \\
\text { years (Avg. 2004-05 and Avg. 2002-2003) }\end{array}$} & & & & 16 & \\
\hline & & & & & & 0 & \\
\hline $\begin{array}{l}\text { 1E) Environmental } \\
\text { orientation }\end{array}$ & 1) Waste recycling & $\%$ of recycled waste & N.A. & N.A. & - & $2.8 \%$ & - \\
\hline \multicolumn{8}{|c|}{ 2) General economy and related cultural aspects } \\
\hline \multirow{2}{*}{ 2A) Income } & 1) Local Net Income & Per-person income (in Euro) (1991) & 463.10 & 607.08 & 535.09 & 583.50 & 551.23 \\
\hline & 2) Added Value & Per person added value (2004) & 18.400 & & & 24.500 & \\
\hline 2B) Economical & 1) Distribution of economic & $0 / 1$ ativition in the $1^{\text {st }} 2^{\text {nd }}$ and $2^{\text {rd }}$ anoten & $2700 /$ & $000 /$ & $15 n 0 /$ & $070 /$ & $\cap 60 /$ \\
\hline
\end{tabular}




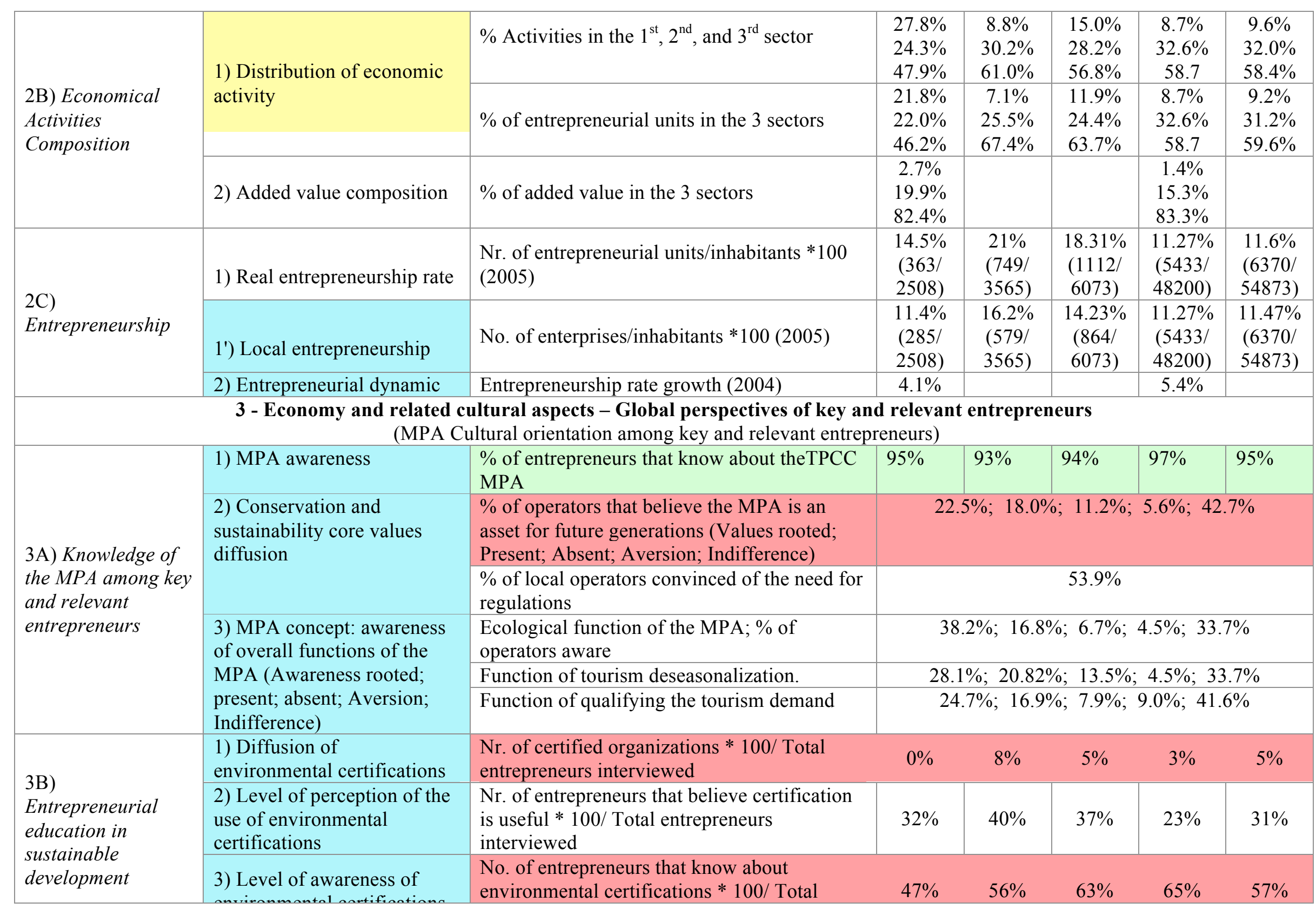




\begin{tabular}{|c|c|c|c|c|c|c|c|}
\hline \multicolumn{8}{|c|}{ 4) Key and relevant sectors } \\
\hline \multicolumn{8}{|c|}{$4^{I}-$ Tourism } \\
\hline $\begin{array}{l}\left.4^{\mathrm{I}} \mathrm{A}\right) \text { Weight of the } \\
\text { sector }\end{array}$ & 1) Real structural incidence & $\begin{array}{l}\text { \% local tourism business units in the whole } \\
\text { economy }\end{array}$ & $26.7 \%$ & $25.8 \%$ & $26.1 \%$ & & \\
\hline $\begin{array}{l}\left.4^{\mathrm{I}} \mathrm{A}^{\prime}\right) \text { Weight of the } \\
\text { sector }\end{array}$ & $\begin{array}{l}\text { 1) Structural incidence on the } \\
\text { local economy }\end{array}$ & $\%$ of tourism enterprises in the local economy & $18.8 \%$ & $21.4 \%$ & $19.4 \%$ & & \\
\hline \multirow{4}{*}{$\begin{array}{l}\left.4^{\mathrm{I}} \mathrm{B}\right) \text { Tourism } \\
\text { pressure }\end{array}$} & \multirow{4}{*}{ 1) Settlement pressure } & $\begin{array}{l}\text { Dwellings not occupied by residents/dwellings } \\
\text { occupied by residents }(2001)\end{array}$ & $\begin{array}{c}2.80 \\
(2277 / \\
814)\end{array}$ & $\begin{array}{l}5.70 \\
(5811 / \\
1019)\end{array}$ & $\begin{array}{c}4.41 \\
(8088 / \\
1833)\end{array}$ & $\begin{array}{c}0.71 \\
10291 / \\
14574\end{array}$ & $\begin{array}{c}1.12 \\
(18379 / \\
16407)\end{array}$ \\
\hline & & $\begin{array}{l}\mathrm{Nr} \text { of tourists that can potentially settle in the } \\
\text { area (unsettled tourist population/each } \mathrm{km} \text { of } \\
\text { coast (2001) }\end{array}$ & & 1503.5 & & 981.1 & \\
\hline & & Unsettled tour. pop./resident tour. pop. (2001) & & 10.5 & & 1.1 & \\
\hline & & $\begin{array}{l}\text { Unsettled tour. pop./each } \mathrm{km} \text { of sandy coast } \\
\text { (2001) }\end{array}$ & & 8729.7 & & 2452.8 & \\
\hline \multirow{15}{*}{$\begin{array}{l}\left.4^{\mathrm{I}} \mathrm{C}\right) \text { Potential of the } \\
\text { tourism offer }\end{array}$} & \multirow{8}{*}{ 1) Organized reception } & No. of hotels $(2003)$ & 5 & 16 & 21 & 40 & 61 \\
\hline & & No. of hotel beds (2003) & 390 & 1887 & 2277 & 3662 & 5939 \\
\hline & & No. of complementary activities ('03) & 1 & 6 & 7 & 10 & 17 \\
\hline & & No. of beds in complementary activities ('03) & 1000 & 2238 & 3238 & 2568 & 5806 \\
\hline & & Total beds in organized reception ('03) & 1390 & 4125 & 5515 & 6230 & 11745 \\
\hline & & No. of 5-star (and luxury) hotels & 0 & - & - & 2 & - \\
\hline & & No. of 4-star hotels & 1 & - & - & 14 & - \\
\hline & & No. of 3-star hotels & 3 & - & - & 20 & - \\
\hline & \multirow{4}{*}{ 2) Seasonality of arrival flux } & $\begin{array}{l}\text { Tot. July-August presence/Tot. annual } \\
\text { presence (2001) }\end{array}$ & & $58.1 \%$ & & $48.8 \%$ & \\
\hline & & $\begin{array}{l}\text { Olbia airport arrivals July-August } * 100 / \\
\text { Annual arrivals (2000-2005) }\end{array}$ & \multicolumn{5}{|c|}{$35.4 \%$} \\
\hline & & $\begin{array}{l}\text { Olbia airport arrivals from June to September } \\
* 100 \text { / Annual arrivals }(00-05)\end{array}$ & \multicolumn{5}{|c|}{$62.4 \%$} \\
\hline & & $\begin{array}{l}\text { Olbia airport arrivals from April to October * } \\
100 / \text { Annual arrivals }(2000-2005)\end{array}$ & \multicolumn{5}{|c|}{$83.0 \%$} \\
\hline & \multirow{3}{*}{$\begin{array}{l}\text { 3) Seasonality perceived by } \\
\text { entrepreneurs in sectors }\end{array}$} & $\begin{array}{l}\text { Clients in the high season (July-August) } * \\
100 / \text { Annual clients }\end{array}$ & $63 \%$ & $57 \%$ & $60 \%$ & $49 \%$ & $55 \%$ \\
\hline & & $\begin{array}{l}\text { Clients in the medium-high season (from June } \\
\text { to September) *100/Annual clients }\end{array}$ & $86 \%$ & $86 \%$ & $86 \%$ & $70 \%$ & $79 \%$ \\
\hline & & Clients from April to October * $100 /$ Annual & $98 \%$ & $99 \%$ & $98 \%$ & $85 \%$ & $92 \%$ \\
\hline
\end{tabular}




\begin{tabular}{|c|c|c|c|c|c|c|c|}
\hline & & $\begin{array}{l}\text { Clients from April to October * } 100 \text { / Annual } \\
\text { clients }\end{array}$ & $98 \%$ & $99 \%$ & $98 \%$ & $85 \%$ & $92 \%$ \\
\hline \multirow{34}{*}{$\begin{array}{l}\left.4^{\mathrm{l}} \mathrm{D}\right) \text { Diving tourist } \\
\text { demand segment }\end{array}$} & \multirow{34}{*}{$\begin{array}{l}\text { 1) Diver satisfaction (scale } \\
\text { from } 2 \text { to } 10 \text { ) }\end{array}$} & Water quality & & & 9.03 & & \\
\hline & & Landscape & & & 8.97 & & \\
\hline & & Seabed quality & & & 8.95 & & \\
\hline & & Air quality & & & 8.73 & & \\
\hline & & Beach and coast & & & 8.31 & & \\
\hline & & Hospitality & & & 8.07 & & \\
\hline & & Olbia airport operation & & & 7.82 & & \\
\hline & & Lodging: quality & & & 7.82 & & \\
\hline & & Public green spaces & & & 7.80 & & \\
\hline & & Lodging: ease of reservation & & & 7.75 & & \\
\hline & & Operation of the continent/Sardinia ferry & & & 7.73 & & \\
\hline & & Reception & & & 7.50 & & \\
\hline & & Free time and entertainment & & & 7.42 & & \\
\hline & & Restaurants & & & 7.40 & & \\
\hline & & Noise & & & 7.30 & & \\
\hline & & Port of landing operation & & & 7.27 & & \\
\hline & & Lodging: quality/price ratio & & & 7.19 & & \\
\hline & & Excursion activities and tours & & & 7.16 & & \\
\hline & & Beach cleanliness & & & 7.03 & & \\
\hline & & Cost of the continent/Sardinia ferry & & & 6.96 & & \\
\hline & & Security & & & 6.79 & & \\
\hline & & Developed areas & & & 6.75 & & \\
\hline & & Dock operation & & & 6.63 & & \\
\hline & & Cost of parking & & & 6.55 & & \\
\hline & & Accessibility/Transportation & & & 6.52 & & \\
\hline & & Traffic police effectiveness & & & 6.48 & & \\
\hline & & Traffic & & & 6.35 & & \\
\hline & & Beach equipment & & & 6.29 & & \\
\hline & & Cost of the flight & & & 6.20 & & \\
\hline & & Parking & & & 6.11 & & \\
\hline & & Docking cost & & & 5.83 & & \\
\hline & & Crowding & & & 5.75 & & \\
\hline & & Taxi & & & 5.57 & & \\
\hline & & Beach surveillance & & & 5.43 & & \\
\hline
\end{tabular}




\begin{tabular}{|c|c|c|c|}
\hline & & Prices & 5.15 \\
\hline & & Surveillance & 5.14 \\
\hline & & Information and signs & 5.00 \\
\hline & & Bus & 4.57 \\
\hline & & Restrooms & 4.08 \\
\hline & 2) Diver loyalty & $\begin{array}{l}\text { Percent of divers that have visited the location } \\
\text { more than } 5 \text { times }\end{array}$ & $43 \%$ \\
\hline & 3) Awareness of the MPA & $\%$ of divers that know about the TPCC MPA & $88 \%$ \\
\hline & 4) Diver motivation & No. of eco-wilderness tourists / total divers & $81.2 \%$ \\
\hline \multirow{27}{*}{$\begin{array}{l}\left.4^{\mathrm{I}} \mathrm{E}\right) \text { Sand tourist } \\
\text { demand segment }\end{array}$} & \multirow{27}{*}{$\begin{array}{l}\text { 1) Tourist satisfaction (scale } \\
\text { from } 2 \text { to } 10 \text { ) }\end{array}$} & Water quality & 8.75 \\
\hline & & Landscape & 8.68 \\
\hline & & Air quality & 8.32 \\
\hline & & Beach and coast & 8.02 \\
\hline & & Olbia airport operation & 7.70 \\
\hline & & Hospitality & 7.64 \\
\hline & & Port of landing operation & 7.63 \\
\hline & & Operation of the continent/Sardinia ferry & 7.58 \\
\hline & & Lodging: ease of reservation & 7.40 \\
\hline & & Lodging: quality & 7.32 \\
\hline & & Restaurants & 7.29 \\
\hline & & Free time and entertainment & 7.26 \\
\hline & & Public green space & 7.23 \\
\hline & & Noise & 7.06 \\
\hline & & Reception & 7.03 \\
\hline & & Excursion activities and tours & 6.87 \\
\hline & & Lodging: quality/price ratio & 6.82 \\
\hline & & Dock operation & 6.76 \\
\hline & & Developed areas & 6.70 \\
\hline & & Beach cleanliness & 6.69 \\
\hline & & Security & 6.57 \\
\hline & & Accessibility/Transportation & 6.38 \\
\hline & & Cost of the continent/Sardinia ferry & 6.35 \\
\hline & & Traffic police effectiveness & 6.20 \\
\hline & & Docking cost & 6.17 \\
\hline & & Traffic & 5.93 \\
\hline & & Surveillance & 5.92 \\
\hline
\end{tabular}




\begin{tabular}{|c|c|c|c|}
\hline & & Beach equipment & 5.92 \\
\hline & & Aquatic sport instruction & 5.84 \\
\hline & & Parking & 5.65 \\
\hline & & Information and signs & 5.62 \\
\hline & & Cost of the flight & 5.54 \\
\hline & & Cost of parking & 5.51 \\
\hline & & Crowding & 5.48 \\
\hline & & Taxi & 5.28 \\
\hline & & Prices & 4.84 \\
\hline & & Bus & 4.30 \\
\hline & & Restrooms & 3.14 \\
\hline & 2) Tourist loyalty & $\begin{array}{l}\text { Percent of tourists that have visited the } \\
\text { location more than } 5 \text { times }\end{array}$ & $35 \%$ \\
\hline & 3) Awareness of the MPA & $\begin{array}{l}\% \text { of tourists that know about the exact } \\
\text { location of the TPCC MPA }\end{array}$ & $62 \%$ \\
\hline & 4) Tourist motivation & $\begin{array}{l}\text { No. of eco (and wilderness) tourists } * 100 / \\
\text { total tourists }\end{array}$ & $63.3 \%$ \\
\hline \multirow{13}{*}{$\begin{array}{l}\left.4^{\mathrm{I}} \mathrm{F}\right) \text { Sailor tourism } \\
\text { demand segment }\end{array}$} & \multirow{9}{*}{$\begin{array}{l}\text { 1) Sailor tourist satisfaction } \\
\text { (scale from } 2 \text { to } 10 \text { ) }\end{array}$} & Water quality & 9.02 \\
\hline & & Air quality & 8.67 \\
\hline & & Beach and coast & 8.27 \\
\hline & & Restaurants & 7.82 \\
\hline & & Reception & 7.20 \\
\hline & & Excursion activities and tours & 7.04 \\
\hline & & Surveillance & 5.86 \\
\hline & & Information and signs & 5.39 \\
\hline & & Prices & 5.29 \\
\hline & 2) Sailor loyalty & $\begin{array}{l}\text { Percent of recreational tourists that have } \\
\text { visited the location more than } 5 \text { times }\end{array}$ & $67 \%$ \\
\hline & 3) Awareness of the MPA & $\begin{array}{l}\% \text { of recreational tourists that know about the } \\
\text { TPCC MPA }\end{array}$ & $93 \%$ \\
\hline & \multirow{2}{*}{$\begin{array}{l}\text { 4) Recreational tourist } \\
\text { motivation }\end{array}$} & $\begin{array}{l}\text { No. of diving ecotourists } * 100 / \text { total sailor } \\
\text { tourists }\end{array}$ & $41 \%$ \\
\hline & & No. of ecotourists $* 100 /$ total sailor tourists & $65 \%$ \\
\hline \multicolumn{4}{|c|}{$4^{I I}-$ Fishing } \\
\hline $\begin{array}{l}4^{\mathrm{II}} \text { A) } M P A \text { objective } \\
\text { sharing }\end{array}$ & $\begin{array}{l}\text { 1) Understanding the benefits } \\
\text { (individual) of the MPA }\end{array}$ & $\begin{array}{l}\% \text { of operators that believe they have had: }> \\
\text { benefits }\end{array}$ & $50 \%$ \\
\hline
\end{tabular}




\begin{tabular}{|c|c|c|c|c|c|c|c|}
\hline $\begin{array}{l}\left.4^{\mathrm{II}} \mathrm{B}\right) \text { Collaborative } \\
\text { potential }\end{array}$ & $\begin{array}{l}\text { 1) Collaboration possibilities } \\
\text { between the MPA and } \\
\text { fishermen }\end{array}$ & $\begin{array}{l}\% \text { of acts hoped for by fishermen consistent } \\
\text { with MPA activities }\end{array}$ & \multicolumn{5}{|c|}{$68.8 \%$} \\
\hline \multirow{4}{*}{$\begin{array}{l}\left.4{ }^{\mathrm{II}} \mathrm{C}\right) \text { Awareness of } \\
\text { the effects of } \\
\text { anthropic activities } \\
\text { on the ecosystem }\end{array}$} & \multirow{2}{*}{$\begin{array}{l}\text { 1) Perception of the } \\
\text { sustainability of local } \\
\text { resources }\end{array}$} & $\begin{array}{l}\text { Perceived intensity of the damage to marine } \\
\text { life caused by trawling }\end{array}$ & \multicolumn{5}{|c|}{$77.8 \%$} \\
\hline & & $\begin{array}{l}\text { Perceived intensity of the damage to marine } \\
\text { life caused by explosives }\end{array}$ & \multicolumn{5}{|c|}{$100 \%$} \\
\hline & $\begin{array}{l}\text { 2) Perception of the anthropic } \\
\text { impact on marine resources }\end{array}$ & $\begin{array}{l}\text { Perception of the lack of surveillance as an } \\
\text { environmental threat }\end{array}$ & \multicolumn{5}{|c|}{$100 \%$} \\
\hline & & $\begin{array}{l}\text { Perception of industrial activities as an } \\
\text { environmental threat }\end{array}$ & \multicolumn{5}{|c|}{$66.7 \%$} \\
\hline $\begin{array}{l}\left.4^{\mathrm{II}} \mathrm{D}\right) \text { Perception of } \\
\text { the social use of the } \\
M P A\end{array}$ & $\begin{array}{l}\text { 1) Perception of the effect of } \\
\text { the MPA on fish stocks }\end{array}$ & $\begin{array}{l}\% \text { of fishermen convinced that the MPA } \\
\text { leads to a greater quality and quantity of fish } \\
\text { caught }\end{array}$ & \multicolumn{5}{|c|}{$43.7 \%$} \\
\hline $\begin{array}{l}\left.4^{\mathrm{II}} \mathrm{E}\right) \text { Effects on the } \\
\text { local economy }\end{array}$ & $\begin{array}{l}\text { 1) Retention of value added } \\
\text { by fishing }\end{array}$ & $\%$ local market sales & \multicolumn{5}{|c|}{$68 \%$} \\
\hline \multicolumn{8}{|c|}{$4^{\text {III }}-$ Building } \\
\hline \multirow{2}{*}{$\begin{array}{l}4^{\mathrm{III}} \text { A) Structural } \\
\text { influence }\end{array}$} & $\begin{array}{l}\text { 1) Real influence of the } \\
\text { sector }\end{array}$ & $\begin{array}{l}\text { No. of construction companies (units) } * 100 / \\
\text { total local number of companies (units) }\end{array}$ & $\begin{array}{c}18.2 \% \\
66 / \\
363\end{array}$ & $\begin{array}{c}22.6 \% \\
169 / \\
749\end{array}$ & $\begin{array}{c}21.1 \% \\
235 / \\
1112\end{array}$ & $\begin{array}{c}20.2 \% \\
1093 / \\
5433\end{array}$ & $\begin{array}{l}20.3 \% \\
1328 / \\
6545\end{array}$ \\
\hline & $\begin{array}{l}\text { 2) Influence of the sector in } \\
\text { the local economy }\end{array}$ & $\begin{array}{l}\text { No. of construction businesses with a local } \\
\text { office } * 100 \text { / total businesses with a local } \\
\text { office }\end{array}$ & $\begin{array}{l}21.4 \% \\
61 / 285\end{array}$ & $\begin{array}{c}26.8 \% \\
155 / 57 \\
9\end{array}$ & $\begin{array}{c}25.0 \% \\
216 / 86 \\
4\end{array}$ & $\begin{array}{c}20.2 \% \\
1093 / 5 \\
433\end{array}$ & $\begin{array}{c}20.8 \% \\
1303 / 6 \\
297\end{array}$ \\
\hline \multirow{4}{*}{$\begin{array}{l}\left.4^{\mathrm{III}} \mathrm{B}\right) \text { Expansion } \\
\text { capacity }\end{array}$} & \multirow{2}{*}{$\begin{array}{l}\text { 1) Additional anthropic } \\
\text { pressure in the MPA }\end{array}$} & $\begin{array}{l}\text { Estimated additional number of inhabitants based } \\
\text { on cities' development plans (Zone B) }\end{array}$ & & & & 470 & \\
\hline & & $\begin{array}{l}\text { Estimated additional number of inhabitants based } \\
\text { on cities' development plans (Zone C) ( }\end{array}$ & 2500 & 150 & 2650 & 1290 & 3940 \\
\hline & \multirow{2}{*}{$\begin{array}{l}\text { 2) Additional territorial } \\
\text { pressure in the MPA }\end{array}$} & 1) Residual volume $\left(\mathrm{m}^{3}\right)$ in the MPA (Zone B) & & & & 47,000 & \\
\hline & & 2) Residual vol. $\left(\mathrm{m}^{3}\right)$ in MPA (Zone $\left.\mathrm{C}\right)$ & 250,000 & 25,000 & 275,000 & 129,000 & 404,000 \\
\hline
\end{tabular}


Appendix 5. Summary of results for the question "Satisfaction about key MPA services and environmental plus services quality evaluation" (See Appendix 1) for the beach tourists and the scuba divers. The factors highlighted in green (corresponding to scores, based on frequency of responses, greater than 8, with the maximum possible score $=10$ ) were identified as opportunities in the SWOT analysis (Appendix 7).

\begin{tabular}{|l|c|c|c|c|}
\hline & \multicolumn{2}{|c|}{ Beach tourists } & \multicolumn{2}{c|}{ Scuba divers } \\
\hline Alternative & $\begin{array}{c}\text { Score } \\
(\mathbf{m a x} \mathbf{1 0})\end{array}$ & $\begin{array}{c}\text { Answer } \\
\text { rate }\end{array}$ & $\begin{array}{c}\text { Score } \\
(\text { max 10) }\end{array}$ & $\begin{array}{c}\text { Answer } \\
\text { rate }\end{array}$ \\
\hline Water quality & $\mathbf{8 . 7 5}$ & $100 \%$ & $\mathbf{9 . 0 3}$ & $100 \%$ \\
\hline Landscape & $\mathbf{8 . 6 8}$ & $100 \%$ & $\mathbf{8 . 9 7}$ & $100 \%$ \\
\hline Air quality & $\mathbf{8 . 3 2}$ & $100 \%$ & $\mathbf{8 . 7 3}$ & $100 \%$ \\
\hline Coast/beach & $\mathbf{8 . 0 2}$ & $100 \%$ & $\mathbf{8 . 3 1}$ & $98 \%$ \\
\hline Hospitality/Kindness & $\mathbf{7 . 6 4}$ & $100 \%$ & $\mathbf{8 . 0 7}$ & $98 \%$ \\
\hline Green & $\mathbf{7 . 2 3}$ & $98 \%$ & $\mathbf{7 . 8 0}$ & $100 \%$ \\
\hline Leisure & $\mathbf{7 . 2 6}$ & $83 \%$ & $\mathbf{7 . 4 2}$ & $87 \%$ \\
\hline Security & $\mathbf{6 . 5 7}$ & $90 \%$ & $\mathbf{6 . 7 9}$ & $93 \%$ \\
\hline Villages & $\mathbf{6 . 7 0}$ & $99 \%$ & $\mathbf{6 . 7 5}$ & $98 \%$ \\
\hline Traffic & $\mathbf{5 . 9 3}$ & $100 \%$ & $\mathbf{6 . 3 5}$ & $95 \%$ \\
\hline Crowding & $\mathbf{5 . 4 8}$ & $93 \%$ & $\mathbf{5 . 7 5}$ & $92 \%$ \\
\hline Manners of jet-skiers, windsurfers.. & $\mathbf{5 . 8 4}$ & $91 \%$ & $\mathbf{5 . 3 7}$ & $98 \%$ \\
\hline Prices & $\mathbf{4 . 8 4}$ & $100 \%$ & $\mathbf{5 . 1 5}$ & $98 \%$ \\
\hline & & & & \\
\hline
\end{tabular}


Appendix 6. Differences and commonalities among key and relevant with regards to their fidelity to the MPA. Percent of answers to the question "How many times have you been to this area? (First time, Second time, Twice before, More than twice, More than 5 times, More than 10 times) are reported.

\begin{tabular}{|l|l|l|l|l|l|l|l|}
\hline & First time & Second time & $\begin{array}{l}\text { Two other } \\
\text { times }\end{array}$ & $\begin{array}{l}\text { More than } \\
\text { twice (less } \\
\text { than 5) }\end{array}$ & $\begin{array}{l}\text { More than } \\
5 \text { times } \\
\text { (less than } \\
10)\end{array}$ & $\begin{array}{l}\text { More than } \\
10 \text { times }\end{array}$ & $\begin{array}{l}\text { Total } \\
\text { number of } \\
\text { interviewees }\end{array}$ \\
\hline $\begin{array}{l}\text { Beach } \\
\text { tourists }\end{array}$ & $30 \%$ & $15 \%$ & $11 \%$ & $9 \%$ & $9 \%$ & $26 \%$ & 184 \\
\hline Scuba divers & $26 \%$ & $12 \%$ & $7 \%$ & $12 \%$ & $12 \%$ & $31 \%$ & 60 \\
\hline Sailors & $6 \%$ & $2 \%$ & $11 \%$ & $7 \%$ & $15 \%$ & $52 \%$ & 46 \\
\hline Total & $26 \%$ & $12 \%$ & $10 \%$ & $9 \%$ & $11 \%$ & $31 \%$ & 290 \\
\hline
\end{tabular}


Appendix 7. Examples of threats and opportunities identified for each socio-economical subsystem through the SWOT analysis.

\begin{tabular}{|c|c|c|c|c|}
\hline Subsystem & Opportunities & Ind. & Imp. & Int. \\
\hline $\begin{array}{l}\text { A) Ecological (social } \\
\text { perception) }\end{array}$ & Marine and coastal resources perceived as high-quality & $\begin{array}{l}4^{\mathrm{l}} \mathrm{D} 1,4^{\mathrm{I}} \mathrm{E} 1, \\
4^{\mathrm{I}} \mathrm{F} 1\end{array}$ & 1 & 2 \\
\hline B) Social & High local educational potential for preschool and primary school children & $1 \mathrm{~A}^{\mathrm{I}}$ & 1 & 2 \\
\hline C) Cultural & $\begin{array}{l}\text { Key individuals that believe in the MPA mission and promote a vision of sustainable } \\
\text { development }\end{array}$ & $(* *)$ & 1 & 1 \\
\hline D) Entrepreneurial & High level of knowledge of the existence of the MPA among local entrepreneurs & $3 \mathrm{~A} 1$ & 1 & 1 \\
\hline D1) Fishermen segment & $\begin{array}{l}\text { Concordance between the aspirations and needs of fishermen and the current and possible future } \\
\text { role of the MPA. }\end{array}$ & $\begin{array}{l}4^{\mathrm{II}} \mathrm{B} 1, \\
4^{\mathrm{II}} \mathrm{C} 1,2\end{array}$ & 1 & 1 \\
\hline E) Touristic & Great appreciation for environmental characteristics and functions of the MPA among tourists & $4^{\mathrm{I}} \mathrm{D} 1$ & 1 & 1 \\
\hline E) Touristic & High loyalty to this location & $\begin{array}{l}4^{\mathrm{I}} \mathrm{D} 2,4^{\mathrm{I}} \mathrm{E} 2, \\
4^{\mathrm{I}} \mathrm{F} 2\end{array}$ & 0 & 2 \\
\hline E) Touristic & $\begin{array}{l}\text { Strong eco-tourism orientation by different tourist groups, particularly of recreational scuba } \\
\text { divers }\end{array}$ & $4^{\mathrm{I}} \mathrm{D} 4,4^{\mathrm{I}} \mathrm{E} 4$ & 1 & 1 \\
\hline $\begin{array}{l}\text { E1) Key segment scuba } \\
\text { divers }\end{array}$ & $\begin{array}{l}\text { Great appreciation for environmental characteristics and functions of the MPA among scuba } \\
\text { divers }\end{array}$ & $4^{\mathrm{I}} \mathrm{E} 1$ & 1 & 1 \\
\hline E1-2) Scuba and sailor & High level of knowledge of the MPA among divers and sailors. & $4^{1} \mathrm{D} 3,4^{\mathrm{I}} \mathrm{F} 3$ & 1 & 1 \\
\hline F) Urban & $\begin{array}{l}\text { Regional regulations that avoid the realization of high-environmental-impact projects on the } \\
\text { coast }\end{array}$ & $(* * * *)$ & 1 & 1 \\
\hline
\end{tabular}

\begin{tabular}{|c|c|c|c|c|}
\hline Subsystem & Threats & Ind. & Imp. & Int. \\
\hline A) Environmental & Perception of a persistency of fish poaching in the MPA & $(* *)$ & 1 & 1 \\
\hline B) Social & $\begin{array}{l}\text { A general increase in crime and the manifestation of a locally "unknown" phenomenon of } \\
\text { juvenile crime and increase in the distribution and use of illegal drugs }\end{array}$ & $\begin{array}{l}\mathrm{D} 4 \\
1 \mathrm{C} 1,1 \mathrm{C} 3 \\
\end{array}$ & 1 & 1 \\
\hline C) Cultural & Lack of knowledge and love of MPA resources among youth & $(* *)$ & 1 & 2 \\
\hline C1) Entrepr. culture & Low level of knowledge and use of environmental certification & 3B3 & 1 & 2 \\
\hline D) Entrepreneurial & $\begin{array}{l}\text { High concentration of investments and activities in a limited space (coastal) and time (high } \\
\text { season) }\end{array}$ & $4^{\mathrm{I}} \mathrm{C} 3,4^{\mathrm{III}} \mathrm{B} 2$ & 1 & 2 \\
\hline D1) Building sector & Overcapacity of building sector & $4^{\mathrm{III}} \mathrm{A}$ & 1 & 2 \\
\hline
\end{tabular}




\begin{tabular}{|c|c|c|c|c|}
\hline E) Touristic & High seasonality in the entire tourism sector & $4^{\mathrm{I}} \mathrm{C} 3$ & 1 & 2 \\
\hline E) Tourism - services & Lack of adequate facilities on beaches and high prices. & $\begin{array}{l}4^{\mathrm{I}} \mathrm{D} 1, \\
4^{\mathrm{I}} \mathrm{E} 1, \\
4^{\mathrm{I}} \mathrm{F} 1\end{array}$ & 0 & 2 \\
\hline E) Tourism- system & Overcrowding during high season & $\begin{array}{l}4^{\mathrm{I}} \mathrm{D} 1, \\
4^{\mathrm{I}} \mathrm{E} 1, \\
4^{\mathrm{I}} \mathrm{F} 1\end{array}$ & 1 & 1 \\
\hline $\begin{array}{l}\text { E1) Key segment scuba } \\
\text { divers }\end{array}$ & Concentration on certain "favorite" dive sites & $(* * * * *)$ & 0 & 1 \\
\hline F) Urban & $\begin{array}{l}\text { High tourism pressure, particularly for structures (houses inhabited by residents / non-residents) } \\
\text { in the two core municipalities }\end{array}$ & $4^{\mathrm{I}} \mathrm{B} 1$ & 1 & 2 \\
\hline F1) Urban - settlements & Development plans exceed area's carrying capacity & $4^{\mathrm{IIII}} \mathrm{B} 1,2$ & 1 & 2 \\
\hline $\begin{array}{l}\text { 2G) Infrastructure and } \\
\text { mobility }\end{array}$ & System under pressure (parking, traffic, crowding) during peak times in certain locations & $\begin{array}{l}4^{\mathrm{l}} \mathrm{D} 1, \\
4^{\mathrm{I}} \mathrm{E} 1\end{array}$ & 1 & 1 \\
\hline
\end{tabular}

Columns key: Ind. = main indicators used, Imp. $=$ importance. Int. $=$ intensity.

(*) Data from the analysis of the MPA Authority internal organization

(**) Data from the key informants analysis

(***) Data from the qualitative analysis of interviews (open questions)

$(* * * *)$ Data from documental investigation

$(* * * * *)$ Data from official scuba diving records 
Appendix 8. Managerial implications: examples of socio-economical actions by the MPAA aimed at the sharing of the MPA's vision (based on the SWOT Analysis).

\begin{tabular}{|l|l|l|}
\hline \multicolumn{1}{|c|}{ Action } & \multicolumn{1}{|c|}{ Primary purpose } & Priority \\
\hline $\begin{array}{l}\text { Creating a modern and technologically advanced information and education centre in the most frequented by } \\
\text { young people street (called the "House of the Sea") }\end{array}$ & $\begin{array}{l}\text { Education and ecotourism } \\
\text { service }\end{array}$ & 1 \\
\hline Activation of capillary environmental education strategy in the schools & Environmental Education & 2 \\
\hline Activation of scholarships on sustainable development and ecotourism & Entrepreneurial education & 3 \\
\hline $\begin{array}{l}\text { Information campaign on the benefits (economic and not-economic) of the no-take conservation strategy in the } \\
\text { MPA }\end{array}$ & Entrepreneurial education & 4 \\
\hline
\end{tabular}

